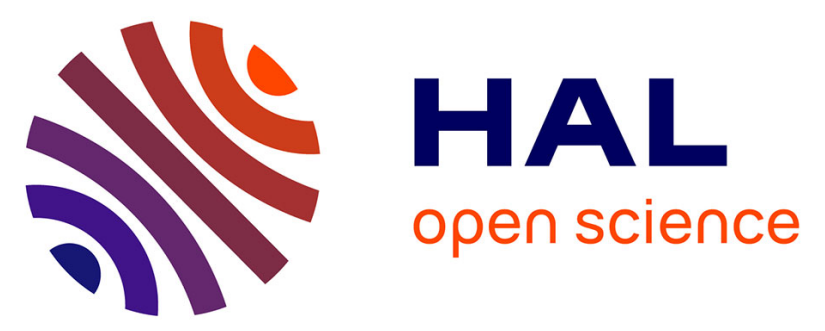

\title{
Structural and Sedimentary records of the Oligocene revolution in the Western Alpine arc
}

Thierry Dumont, S. Schwartz, Stephane Guillot, Thibaud Simon-Labric, Pierre Tricart, Sebastien Jourdan

\section{> To cite this version:}

Thierry Dumont, S. Schwartz, Stephane Guillot, Thibaud Simon-Labric, Pierre Tricart, et al.. Structural and Sedimentary records of the Oligocene revolution in the Western Alpine arc. Journal of Geodynamics, 2012, 56-57, pp.18-38 - GEOD-1101. 10.1016/j.jog.2011.11.006 . insu-00663367

\section{HAL Id: insu-00663367 https://hal-insu.archives-ouvertes.fr/insu-00663367}

Submitted on 26 Jan 2012

HAL is a multi-disciplinary open access archive for the deposit and dissemination of scientific research documents, whether they are published or not. The documents may come from teaching and research institutions in France or abroad, or from public or private research centers.
L'archive ouverte pluridisciplinaire HAL, est destinée au dépôt et à la diffusion de documents scientifiques de niveau recherche, publiés ou non, émanant des établissements d'enseignement et de recherche français ou étrangers, des laboratoires publics ou privés. 


\title{
Structural and Sedimentary records of the Oligocene revolution in the Western Alpine arc
}

\author{
Dumont T., Schwartz S., Guillot S., Simon-Labric T.,Tricart P. \& Jourdan S. \\ ISTerre, CNRS \& Université de Grenoble I, \\ Maison des Géosciences, 1381 rue de la Piscine, BP53, 38041 Grenoble Cedex 9, France \\ Corresponding author: Thierry Dumont \\ thierry.dumont@ujf-grenoble.fr
}

\begin{abstract}
The northwestwards-directed Eocene propagation of the Western Alpine orogen is linked with (1) compressional structures in the basement and the Mesozoic sedimentary cover of the European foreland, well preserved in the External Zone (or Dauphiné Zone) of the Western Alps, and (2) tectono-sedimentary features associated with the displacement of the early Tertiary foreland basin. Three major shortening episodes are identified: A pre-Priabonian deformation D1 (N-S shortening), supposedly linked with the Pyrenean-Provence orogeny, and two Alpine shortening events D2 (N-to NW-directed) and D3 (W-directed). The change afficher lignesfrom D2 to D3, which occurred during early Oligocene time in the Dauphiné zone, is demonstrated by a high obliquity between the trends of the D3 folds and thrusts, which follow the arcuate orogen, and of the D2 structures which are crosscut by them. This change is also recorded in the evolution of the Alpine foreland basins: the flexural basin propagating NW-wards from Eocene to earliest Oligocene shows thin-skinned compressional deformation, with syn-depositional basin-floor tilting and submarine removal of the basin infill above active structures. Locally, a steep submarine slope scar is overlain by kilometricscale blocks slided NW-wards from the orogenic wedge. The deformations of the basin floor and the associated sedimentary and erosional features are kinematically consistent with D2 in the Dauphiné foreland. Since $\sim 32$ Ma ago, the previously subsiding areas were uplifted and the syntectonic sedimentation shifted westwards. Simultaneously, the paleo-accretionnary prism which developped during the previous, continental subduction stage was rapidly exhumed during the Oligocene collision stage due to westward indenting by the Adriatic lithosphere, which likely enhanced the relief and erosion rate. The proposed palinspastic restoration takes into account this two-stage evolution, with important northward transport of the distal passive margin fragments (Briançonnais) involved in the accretionnary prism before the formation of the western arc, which now crosscuts the westward termination of the ancient orogen. By early Oligocene, the Ivrea body indentation which was kinematically linked with the Insubric line activation initiated the westward escape and the curvature of the arc was progressively acquired, as recorded by southward increasing counter-clockwise rotations in the internal nappes. We propose that the present $\mathrm{N}-\mathrm{S}$ trend of the Ivrea lithospheric mantle indenter which appears roughly rectilinear at $\sim 15 \mathrm{~km}$ depth could be a relict of the western transform boundary of Adria during its northward Eocene drift. The renewed Oligocene Alpine kinematics and the related change in the mode of accomodation of Africa-Europe convergence can be correlated with deep lithospheric causes, i.e. partial detachment of the Tethyan slab and/or a change in motion of the Adria plate, and was enhanced by the Edirected rollback of the eastern Ligurian oceanic domain and the incipient Ligurian rifting.
\end{abstract}




\section{Keywords}

Western Alps, continental subduction, collision, foreland basins, westward escape

\section{Introduction}

The Alpine orogen resulted from the collision of the Adriatic microplate, supposedly linked with Africa, with the European continental margin of the Western Tethys ocean during Early Tertiary times. The Africa-Europe convergence was oriented N-S (Dewey et al., 1989; Rosenbaum et al., 2002) but the Adriatic microplate may have moved independantly during the Tertiary (Channel, 1996; Handy et al., 2010). The Western Alpine orogen is well documented but the paleogeographic restoration is still debated (Schmid et al., 2004; Handy et al., 2010). The arcuate shape has been interpreted in different ways, involving i) pre-Alpine (Tethyan) paleogeographic inheritance on the European margin side (Lemoine et al., 1989), or due to the shape of the Adriatic indenter (Tapponnier, 1977), ii) purely collisional origin due to indenter-induced body forces causing variable transport/spreading directions, referred to as the radial outward model (Platt et al., 1989b), iii) plates motion with rotation of the Adriatic microplate and/or part of the Penninic foreland (Vialon et al., 1989; Collombet et al., 2002 and refs. therein), or with change in relative motion of the Adriatic microplate (Schmidt \& Kissling, 2000; Ford et al., 2006 and refs. therein). As proposed by Handy et al (2010), a sharp change occurred at about $35 \mathrm{Ma}$, in the motion and configuration of the Adriatic microplate, and the subsequent Oligocene dynamics could be partly driven by the initiation of the Ligurian rollback subduction and associated eastward retreat (Vignaroli et al., 2009).

Nevertheless, the finite radial shape of the Western Alpine arc cannot be restored simply without facing overlap problems in its central part. This geometry results from progressive deformation events from Eocene to Miocene, and involves rotations of ancient kinematic indicators during younger deformation stages, especially in the Internal Zones (fig. 1; Choukroune et al., 1986; Collombet et al., 2002; Rosenbaum \& Lister, 2005). There is evidence of anticlockwise rotation of transport directions through time, both in the External and in the Internal Zones (e.g. Lemoine, 1972; Merle \& Brun, 1981; Steck, 1998; Schmid \& Kissling, 2000; Ceriani et al., 2001), so that the initial geometry can only be restored through consideration of incremental displacements (Capitanio and Goes, 2006).

The present arc is outlined by a lithospheric thrust ramp commonly called "Crustal Pennine Thrust" (CPT, fig.1), presently exposed at the front of the Internal Zones which are metamorphic, and corresponding to at least $80 \mathrm{~km}$ offset of the moho along the ECORSCROP profile (Gellec et al., 1990; Kissling et al., 2006; Lardeaux et al., 2006). This feature occurred quite late in Alpine history and does not fit the earlier Alpine kinematics and geometry, particularly in the Internal Zones (Schmid \& Kissling, 2000; Dèzes et al., 2004; Thomas et al., 1999). However, in the footwall of the «Crustal Pennine Thrust», that is, in the External Zone, the displacements and rotations are moderate (Gratier et al., 1989; Aubourg et al., 1999). It is thus possible to observe the interference between differently oriented shortening stages during the development of continental collision more easily than in the Internal Nappes stack whose building was polyphased and which was involved in continental subduction.

The aim of this paper is to depict how the Alpine Oligocene plate revolution is recorded within the external part of the Alps, both in terms of deformation and of sedimentary evolution through times. The considered arguments are (i) the interference structures and variably-directed nappe displacements which are found in the External Zone within the Dauphiné and southern Subalpine domains of the western and southwestern parts of the arc (fig. 2), and (ii) synsedimentary deformation and displacements of the Tertiary foreland basins over the External Zone. A review of structural, metamorphic and chronological data 
available from the whole western and central Alps provides an integrated framework for the investigated kinematic changes.

Cross-folding in the External Zone has been previously interpreted as an interplay between Pyrenean and Alpine shortening events, that is between the Iberian and Apulian plates kinematic effects (i.e. Lemoine, 1972; Ford, 1996). It is shown here that a significant part of $\mathrm{N}-\mathrm{S}$ shortening is actually younger than the «Pyrenean-Provence » event and just preceeded the westward Oligocene propagation of the Internal Nappes. It is proposed that these structures, which formed around the Eocene-Oligocene boundary, are linked to the NW propagating Adria-Europe collision during the early stage of the Alpine orogenesis.

\section{Structural and stratigraphic setting}

The External Zone of the Western Alps (fig.1) is composed of elevated crystalline basement massifs having recorded the Hercynian orogeny (Corsini et al., 2004; Guillot et al., 2009), surrounded by a Tethyan sedimentary cover of Mesozoic age and scattered remnants of Cenozoic Alpine foreland basins (e.g. de Graciansky et al., 2010, and refs therein). The basement massifs trend NE-SW from Mont-Blanc to Belledonne, and NW-SE in the southernmost part of the Alpine arc (Argentera). The NE-SW trend corresponds to the Hercynian fabric reactivated in large-scale tilted fault blocks during the Tethyan rifting (e.g. Lemoine et al., 1986 and references therein). This part of the European palaeomargin of the Tethys suffered approximately E-W shortening in the footwall of the CPT during Alpine orogenesis (e.g. Dumont et al., 2008 and refrences therein), The Pelvoux massif, which is located at the transition between the NE-SW and NW-SE trends, has a sub-circular shape (fig. 2) because it suffered several non-coaxial Pyrenean and Alpine shortening events (Ford, 1996; Dumont et al., 2008).

This compressional interference structure was first affected by $\mathrm{N}-\mathrm{S}$ sortening events commonly assigned to the «Pyrenean-Provence » stages, during late Cretaceous to Eocene times (Meckel et al., 1996 ; Ford, 1996; Michard et al., 2010). Subsequently, that is during late Eocene to earliest Oligocene, a first set of non-metamorphic nappes («Embrunais Nappes », fig. $1 \&$ fig. 2), composed of late Cretaceous deep-water sediments likely of oceanic origin and of Mesozoic cover detached from the distal and middle parts of the European palaeomargin, were gravitationally transported towards more proximal portions of the European foreland (Kerckhove et al., 1978; Merle \& Brun, 1981; Ford et al., 2006). It is observed that the later stages of thrust system propagation (from middle Oligocene onwards) were more radially directed (Choukroune et al., 1986; Platt et al., 1989a). The main associated crustal-scale structure corresponds to the «Crustal Pennine Thrust» CPT (fig. $1 \&$ 2), which represents the limit between the foreland (including the early Embrunais Nappes; E, fig. 1) and the metamorphic, Internal Nappes stack (Sue and Tricart, 2006). The Pelvoux massif was lying in the footwall of both the NW-ward directed Embrunais Nappes and the W-ward directed Internal Nappes, which crosscut the latter (Dumont et al., 2008). This explains its antiformal dome geometry.

The Mesozoic series overlains a sharp late Hercynian unconformity, developed as a peneplanation surface which became flat and horizontal over the whole study area between late Carboniferous and early Triassic times. The so-called Dauphiné type (central part of the External Western Alps) and Subalpine Mesozoic sequence (Subalpine massifs and southern part of the arc; fig. 2) is characterised by the following formations :

- Late middle to Late Triassic: thin peritidal dolomites showing only minor thickness variation, which implies that the whole area remained flat and horizontal until near endTriassic times. The Triassic sequence, which is only made of carbonates in Dauphiné, remains attached to the basement, but it thickens further S and SE in the SE-France basin (Courel et al., 1984), and also in the Internal Nappes, including evaporites which provide widespread 
detachment layers. The Triassic sequence is capped by thin alkaline to transitional basaltic flows in Dauphiné, which may indicate the startpoint of Tethyan rifting.

- Lowermost Liassic (early to middle Hettangian) transgressive platform carbonates grade upwards into thick early Liassic to Middle Jurassic hemipelagic marls and limestones. These latter formations are coeval with repeated stages of extensional faulting (Chevalier et al., 2003; Domergues et al., in press), and show important thickness and facies changes due to differential subsidence (Lemoine et al., 1986; Dumont, 1998).

- Late Jurassic to early Cretaceous pelagic, post-rift carbonates are rarely preserved in the Dauphiné massifs, but the post-rift unconformity is locally observed thanks to Tithonian limestones directly overlying the Hercynian basement (Barféty \& Gidon, 1983). The post-rift cover is widespread further to the west and south, providing the thick carbonate series of the Subalpine massifs.

- The Upper Cretaceous formations recorded the earliest compressional deformation (preSenonian folding) in the Devoluy Subalpine massif, due to the motion of the Iberian block (Meckel et al., 1996).

- A sharp pre-Priabonian continental erosion surface cuts the Mesozoic sequence downwards from the southeast (Maritime Alps) to the Pelvoux massif further northwest (Gupta \& Allen, 2000). This event was linked with exhumation of the Pelvoux basement and folding of the Dauphiné and Subalpine Mesozoic cover, and it is assigned to the Iberian plate motion (Gidon, 1979; Ford, 1996). Later on, the subsidence due to flexural bending of the European foreland underneath the propagating Alpine wedge (Sinclair, 1997) led to the deposition of a transgressive sequence including Middle to Late Eocene platform limestones (Pairis, 1988), hemipelagic Globigerina marls and finally thick turbiditic sandstones/shales alternations dated latest Eocene-early Oligocene (Ravenne et al, 1987; Joseph \& Lomas, 2004). The Paleogene sediments, which are widespread in the southern part of the Western Alps, are capped by a characteristic formation containing olistostrome over much of the Western Alpine arc ( «Schistes à blocs »; Kerckhove, 1964) and by the gravity-driven emplacement of the first "exotic" nappes in the basinal setting (Kerckhove, 1969; Campredon, 1977).

\section{Structure of the Dauphiné-Subalpine foreland before the Adria-Europe collision 3.1 Hercynian and Tethyan inheritance}

The structure of the External Crystalline basement massifs in the Western Alps (Mt Blanc, Belledonne, Pelvoux; fig. 1) is strongly influenced by the Permo-Carboniferous External crystalline shear zone trending $\mathrm{N} 30^{\circ} \mathrm{E}$ and including local N-S strike-slip faults (Guillot et al., 2009). The orientation of the Hercynian petrofabric changes to $\mathrm{N} 140^{\circ} \mathrm{E}$ in the Argentera massif (Corsini et al., 2004). It can be used as a post-Permian deformation marker.

The Dauphiné basement massifs, between Belledonne and Pelvoux, represent NS-trending Jurassic tilted blocks (Fig. 3; Lemoine et al., 1986). They result from reactivation of the Hercynian fabric and are subparallel to it, but they were sollicitated obliquely by Tethyan synrift extension (NW-SE ; Lemoine et al., 1989 ; Dumont et al., 2008). Alpine inversion consists mainly of buttressing in the hangingwall of master rift faults and shortcuts in their footwall. Basement shortening involves both folding and thrusting. In the Argentera massif, maximum burial is estimated at 4.8 to $7 \mathrm{~kb}$ (Sanchez et al., 2011b), but in the Pelvoux massif the basement deformation processes are still debated considering the more moderate burial setting (Ford, 1996; Dumont et al., 2008). Compressional deformation increases eastwards, approaching the Crustal Pennine Thrust. There is no evidence for compressional reactivation of the extensional boundary faults. The first-order wavelength of compressional structures is of the same order of magnitude than the major tilted blocks width: i.e., the Grandes Rousses basement anticline is superimposed on a $10 \mathrm{~km}$-wide tilted block (Dumont et al., 2008). 
Conversely, the Pelvoux basement massif has a sub-circular shape which is best explained by the interplay between several, non-coaxial shortening events. It is cored by a relatively homogeneous late Hercynian granite (Guerrot \& Debon, 2000) with little evidence of important variations in the syn-rift series around the massif (Barféty, 1988).

\subsection{Pre-Priabonian structures (D1)}

The Alpine flexural basin floor recorded compressional deformation before the onset of sedimentation, which onlapped a locally rugged topography (Gupta \& Allen, 2000). A preSenonian event produced local folding of the Mesozoic sequence in basinal setting, involving gravity sliding close to the platform edge (Michard et al., 2010). A younger, basementinvolved compressional event is documented by high-angle basement thrusts sealed by Priabonian sediments which are found in the south and SW Pelvoux areas (a, fig. 3; Gidon et al., 1980; Ford, 1996). The associated kinematic indicators in the footwall Mesozoic sediments indicate a S-SW transport direction consistent with another set of basement thrusts located further north (b, fig. 3) but not sealed by the Paleogene sediments except at their southeastern termination, and which are assigned to the same shortening event. All these prePriabonian structures are tilted by younger EW shortening events (Dumont et al., in press).

This pre-Priabonian compressional event D1 caused an important exhumation of the whole southern part of the Pelvoux massif with complete removal of the Mesozoic stratigraphic section by continental erosion. The pre-Priabonian truncation surface is also found on the northern side of the Pelvoux massif (Barbier et al., 1973), allowing the underlying Mesozoic sequence to be completed northwards up to Upper Jurassic. There, this surface is onlapped southwards by coarse fluvial conglomerates at the bottom of the Flysch des Aiguilles d'Arves Paleogene fm., partly sourced by the Pelvoux cristalline basement (Ivaldi, 1987). The southern Subalpine domain, located to the SE of the Pelvoux massif (fig. 2), developed a large wavelength uplift with NW-ward truncation of the Upper Cretaceous to Jurassic sequences before the Eocene transgression.

It is noteworthy that the trends of the structural and tectono-sedimentary features related with this D1 compressional event are strongly oblique or even sub-perpendicular to the present orogen in the southern part of the arc, represented by the CPT.

\section{Foreland subsidence and deformation: NW-ward orogen propagation during Eocene 4.1 Early Alpine deformation (D2)}

An important amount of N-S convergence and northward displacement of the Alpine orogenic wedge with respect to the European foreland is considered in the Central and Eastern Alps during late Eocene times (Froitzheim et al., 1994 ; Schmid \& Kissling, 2000 ; Dèzes et al., 2004), requiring either a major sinistral-oblique accomodation zone at the western end of the early alpine orogen as postulated by Ricou \& Siddans (1986), or a strongly oblique oceanic subduction of the Piedmont ocean and further collision in the Western Alps (Handy et al., 2010). The External western Alps provide kinematic data corresponding to this deformation stage, both in the cristalline basement of the Pelvoux area and in the surrounding Mesozoic and Tertiary sedimentary cover. Important northward to NW-ward displacements occurred at the southern and eastern sides of the Pelvoux massif, i.e. the "Perron des Claux » thrust (Vernet, 1966), which can be followed laterally over more than $30 \mathrm{~km}$ (PDC, fig. 4). In the southern Pelvoux area (site 1, fig. 4), it crosscuts the Meso-Cenozoic cover, and further north it detaches thin basement slices in the eastern Pelvoux region (sites 2 to 4, fig. 4). The propagation of the PDC thrust from the Meso-Cenozoic cover down to the Hercynian basement towards the north can only have occurred provided that the latter had been previously uplifted (due to pre-Priabonian shortening, D1, §3.2). 
The PDC thrust probably connects further north to the « Madeleine » thrust which duplicates the Eocene sequence over the Combeynot basement unit (site 5, fig. 4 ; Barbier et al., 1973). The deformation in its footwall at sites 1 and 4 indicate a NW-ward transport. The PDC thrust has been deformed during several younger Alpine events, as shown by (i) severe overprint by top-to-the-west shearing in the footwall of the Crustal Pennine Thrust (site 11: Pêcher et al., 1992 ; Butler, 1992; Simon-Labric et al., 2009), (ii) long wavelength folding (fig. 4), (iii), eastward dip caused by differential uplift of the Pelvoux massif with respect to Internal Nappes during the Neogene (Tricart et al., 2000) and (iiii) offset of the thrust surface by several late orogenic NE-SW dextral strike-slip faults.

Several reverse faults are found in the footwall of the PDC roof thrust, which are also N- to NW-directed. The Pelvoux thrust (PeT, fig. 4) is associated with $\mathrm{N}$-directed imbricates in the lower Mesozoic sediments (Pêcher et al., 1992 and personal data); the Combeynot thrust (CoT) and Meije thrust (MeT) transport folded basement over the Jurassic cover further north. The Meije thrust climbs section in its footwall towards the north, but has an apparent NEward dip due to further tilt. The hangingwall basement of the Meije and Combeynot thrusts include large wavelength ramp anticlines involving the granitic core, the gneissic envelope and the Triassic-lower Liassic sedimentary cover (fig. 4). The Mesozoic cover in the footwall of the Meije and Combeynot thrusts contains ENE-WSW trending drag folds, and the sole of the Combeynot thrust sheet shows a top-to-the NW shear band (Authemayou, 2002).

There is some evidence that the motion of the PDC thrust and of the associated Pelvoux, Meije and Combeynot thrusts occurred during earliest Oligocene times. The Combeynot shear band yielded a lowermost Oligocene ${ }^{40} \mathrm{Ar} /{ }^{39} \mathrm{Ar}$ age (Simon-Labric et al., 2009). Soft sediment deformation is recorded in the very top of the Paleogene sediments at several localities, indicating top-to-the NW displacements associated with the PDC thrust: to the SE of the Pelvoux, its Meso-Cenozoic hangingwall sequence is overlain by a thick Tertiary olistostrome (« complexe d'Orcières », Debelmas et al., 1980) beneath the Embrunais Basal Thrust. $\mathrm{N}$ to NW recumbent isoclinal folding is sealed by this olistostrome and vanishes laterally in it (Kerckhove et al., 1978). Further west, Gidon \& Pairis (1980) and Butler \& McCaffrey (2004) provide evidence for NW-directed transport in the footwall of the PDC thrust, which occurred during or very soon after the deposition of the uppermost Paleogene flysch sediments (Dumont et al., in press). Similar syn-sedimentary deformation criteria are found along the northern continuation of the PDC thrust (Bravard \& Gidon, 1979). The olistostrome representing the very top of the Paleogene sedimentary sequence is locally dated early Oligocene (Mercier de Lépinay \& Feinberg, 1982).

The D2, top-to-the N to NW deformation of the Dauphiné foreland is related with the emplacement of the earliest Alpine nappes (Embrunais Nappes, Dumont et al., 2008), whose remnants are found immediately to the SE of the Pelvoux massif (fig. 1, 2, 4, 5). These nappes, made of oceanic and continental margin sediments, are derived from the uppermost part of the accretionnary wedge as shown by their very low metamorphic grade. They were emplaced initially in basinal setting by the way of gravity processes (Kerckhove, 1969) and they finally covered a much larger part of the Dauphine and Subalpine forelands than their present remnants, with a significant thickness of 4 to $8 \mathrm{~km}$ over part of the Pelvoux massif (Waibel, 1990) and the Argentera massif (Labaume et al., 2008) whose basement exhumation occurred recently (Sanchez et al., 2011a). Some other remnants of these early Alpine nappes consist of the Prealps and the Ligurian flysch nappes (P, L, fig. 1).

\subsection{Foreland basin propagation and orogen migration during the Eocene}

The Eocene flexural basin propagated firstly over the Briançonnais part of the European palaeomargin during early to middle Eocene. Its basal infil covers unconformably the Briançonnais upper Cretaceous to Paleocene deep marine sequences without any evidence of 
emersion. The coastal migration reached more proximal parts of the Tethyan margin, that is the southern Subalpine, Dauphiné and Helvetic domains, during middle to late Eocene (Priabonian; Ford et al., 2006, and refs herein). The basin floor is marked by a sharp transgressive surface, locally unconformable (Pairis et al., 1984), because this area had been previously emerged due to the Pyrenean-Provence compressional events (D1). The propagation of the basin over it during late Eocene to earliest Oligocene times is marked by a rapid deepening due to flexural subsidence: the facies grade upwards from coastal limestones to hemipelagic foraminiferal marls and thick turbiditic sandstone series, locally named "Grès d'Annot », "Grès du Champsaur », «Flysch des Aiguilles d'Arves » and "Grès de Taveyannaz » from south to north, respectively. As expected in a flexural basin setting (Sinclair, 1997), the diachroneity of this transgressive sequence over the whole Eocene time span is shown by compiling stratigraphic data (fig. 6, left).

This Eocene propagation and coastal migration occurred towards the $\mathrm{N}$ - to NW in the southern Subalpine domain (Kerckhove, 1969; Guardia \& Ivaldi, 1987) and in the Helvetic realm (Kempf \& Pfiffner, 2004; Ford et al., 2006), apart from a SW-ward lateral propagation and confinement at the western termination of the basin (Maritime-Alps to Haute-Provence; Sztrakos \& Du Fornel, 2003; Puigdefabregas et al., 2004; Campredon \& Giannerini, 1982). Sediment supply from the south and northward or NW-ward sedimentary transport directions of the distal deltaic fans (Ravenne et al., 1987; Callec, 2001) are in agreement with this $\mathrm{N}$ to NW direction of propagation of the lithospheric flexure. However, as pointed by Ford et al. (2006), the geometry of the Eocene flexural basin has been heavily distorted by the younger development of the Alpine arc.

The starved infill of the Paleogene flexural basin bears evidence of synsedimentary deformation preceeding the emplacement of the first gravity-driven nappes and of the accretionnary wedge having caused the $\mathrm{N}$ to $\mathrm{NW}$-directed deformation D2. Even in its western termination, $\mathrm{N}$ to $\mathrm{NW}$-ward propagation of deformation is recorded during the Late Eocene (Stanley, 1980 ; Tempier, 1987) and the Grès d'Annot in Maritime-Alps suffered NW-directed basin floor deformation, documented by NW- or SE-directed onlaps (Ravenne et al., 1987; Euzen et al., 2004; Smith \& Joseph, 2004) or sequences architecture (Broucke et al., 2004). Compressional basin-floor deformation is also demonstrated by the occurence of largewavelength removal of the Paleocene section prior to the first Embrunais Nappes emplacement. This feature is best documented across a NW-SE cross-section (fig. 7), which is trending "orogen-parallel" with respect to the present arc, contrary to the more classical NESW profiles found in the litterature (e.g. Ford et al., 1999). This removal, which took place in a basinal setting as demonstrated by the permanent occurrence of an olistostrome over the surface, is found over two large-wavelength anticlines corresponding to the Embrun halfwindow and to the Barcelonnette window (fig. 7) where the Paleocene series is missing beneath the nappes. As these areas correspond to the Jurassic Vocontian basin, this erosion was probably caused by an uplift due to an incipient structural inversion of this basin. The relationships between Paleogene basin floor folding and erosion can be observed to the south of the Barcelonette window, SE of Barcelonette city (fig. 7, 8). The Mesozoic series are locally affected by thin-skinned deformation, showing a tight, EW trending and northward directed recumbent anticline cored by Triassic evaporites (Terre Plaine fold, fig. 8). The Paleogene flysch series (Grès d'Annot fm.) have been completely eroded above the fold hinge, and the truncation surface outcrops further south, over the normal limb. Here, the evidence for Paleogene syndepositional activity of the fold consist of (1) southeastward-tilt of the hemipelagic Globigerina marls, which are onlapped by the lower part of the Grès d'Annot formation (upper fig. 8, left; Kerckhove, 1974) and by a marker layer of conglomeratic debris-flow usually occurring $\sim 300 \mathrm{~m}$ above the base of the formation (Jean, 1985; Joseph \& Lomas, 2004), (2) northwestward erosional truncation of the Grès d'Annot fm., from $>600 \mathrm{~m}$ 
thick to zero in about $5 \mathrm{~km}$ across the Bonnette pass (fig. 8, 9). The truncation surface represented a NW-dipping paleoslope presently incised by several valleys (fig. 8, top and fig. 9) and capped by the olistostrome. This submarine erosional event seems to have followed or to have occurred in association with soft-sediment deformation and normal faulting in the Grès d'Annot further southeast (Bouroullec et al., 2004) which may indicate gravitational unstability.

The paleoslope together with the olistostrome are overlain by kilometric-scale blocks of Mesozoic sedimentary cover derived from the Briançonnais and Provence domains (fig. 8; location A fig. 2). We propose to regard these blocks as olistoliths and not as tectonic thrust sheets, mainly because there is no evidence of tectonic shear zones at their base. They are laid over basinal clastic deposits covering a kilometric-scale submarine paleoslope which truncates the Eocene flysch stratification, also with no evidence of tectonic contact (fig. 10, bottom). Similar olistoliths of Briançonnais origin are described further SE, to the SE of the Argentera massif (Lanteaume, 1990). These blocks show different stratigraphic signatures, indicating that they were slided from a paleogeographic hinge zone inherited from the Tethyan rifting (fig. 11, right) and inverted during the Paleogene. Some of them contain Provence-type, reefal upper Jurassic facies ( $\log 1$, Mourre Haut and Grande Séolane units) which supports the hypothesis of a southern provenance, consistent with the interpretation of gravity sliding from the northern edge of the Provence platform. One of them shows an important erosional gap beneath the Tethyan breakup unconformity (log 3, fig. 11), a typical signature of a hangingwall block. It is noteworthy that very similar anomalies are found in a stack of "thrust sheets" in the Briançonnais nappes stack near the Galibier pass, that is $\sim 90 \mathrm{~km}$ further NNW (fig. 11, left, and location B fig. 2). In this latter locality, which lies in the hanginwall of the CPT, out-of-sequence thrusting associated with D3 (§ 5.1) makes difficult to restore the initial order of the units, but fig. 11 (left part) gives a tentative correlation based on stratigraphic arguments. Nevertheless, the similarities between sites A (Restefond pass) and B (Galibier pass), located in the footwall and in the hangingwall of the CPT, respectively, are to be considered regarding the restoration of the Internal zones $(\S 6)$ and their displacement during the collision stage $(\S 5.1)$. Above these blocks initially emplaced by gravitational processes, the bulk of Embrunais nappes is made of Helminthoid flyschs series of late Cretaceous to Paleocene age (Kerckhove, 1969), obducted from the oceanic realm.

To sum up, the tectono-sedimentary behavior of the Paleogene flexural basin is documented by onlaps and submarine erosion associated with basin floor folding during and soon after its Priabonian to early Oligocene infill. This shortly preceeded the D2 shortening episode recorded in the Dauphine foreland and the emplacement of the Embrunais nappes. All these features can be consistently integrated in the NW-directed propagation model of the Alpine orogen from Eocene to early Oligocene times.

\subsection{Crustal record of continental subduction during the Eocene}

According to several authors, the propagation of the Alpine orogen during the Eocene is maintained by continental subduction processes (Berger \& Bousquet, 2008, and refs. herein). Following this, the shallow level features described above must be compared to the deep crustal record of the Internal Zones, which exhibit a wide range of European continental margin units gradually involved in the subduction channel during the Paleogene. Reviews of geochronological and tectono-metamorphic data (e.g. Berger \& Bousquet, 2008 and Bousquet et al., 2008) indicate that high-pressure metamorphism occurred over a long time span between 70 and $35 \mathrm{Ma}$ ago, while there is little evidence for an elevated orogen at that time considering the relatively low erosion budget (Kühlemann, 2000). 
The diachroneity of involvement of the distal margin units, especially the Briançonnais domain, in the continental subduction zone is illustrated in fig. 6 (middle part) showing highpressure and exhumation ages plotted from some selected references between the oceanic units and the proximal European margin represented by the External Zone. It documents the overlap of high-pressure and brittle exhumation ages in different fragments of the Briançonnais crust, which is in agreement with their gradual accretion to the orogenic wedge. This evolution is coeval with the migration of the Paleogene flexural basin towards the Dauphiné/Helvetic foreland (fig. 6, left part), spanning the whole Eocene stage. In the Internal Zones, the kinematic indicators corresponding to the early Alpine deformation stages are predominantly northward directed $(\S 5.3)$, consistent with the tectono-sedimentary evidence from the flexural basin and from the foreland. The structures of the resulting accretionnary buildup, presently exhumed in the Internal arc, are best shown across a NS-trending crosssection (Tricart \& Schwartz, 2006). All these features are consistent with the orientation of Africa-Europe convergence during Paleogene after Rosenbaum et al. (2002). Considering the palinspastic reconstruction of Schmid \& Kissling (2000), the propagation rate of the foreland basin after Ford et al. (2006), and the subduction rate of the distal parts of the European margin (Berger \& Bousquet, 2008), the rate of propagation of the orogen would have been of the same order of magnitude than the Africa-Europe convergence rate $(\sim 1 \mathrm{~cm} / \mathrm{yr})$. However this estimation is poorly constrained and it assumes that Adria was not moving independantly from Africa during Eocene times, which is still debated because of the possible occurrence of spreading of the Ionian sea between Africa and Adria before $35 \mathrm{Ma}$ (Michard et al., 2002; Handy et al., 2010). Anyway, as pointed by Handy et al. (2010), the northward displacement of Adria during Eocene fits the palinspastic width of distal European margin (about 120 to $150 \mathrm{~km}$ of Briançonnais domain; Lemoine et al., 1986 ; Stampfli et al., 1998, 2002) predicted to have been consumed in the subduction zone. Considering the Adria plate motion direction, the tectonic transport criteria in the Internal nappes and the evidence of N-NW propagation of the foreland flexural basin during Eocene, an important northward amount of displacement of the Briançonnais units, presently spreading around the arc, is needed during the early stages of Alpine continental subduction. This was postulated by the model of Ricou \& Siddans (1986) and this is consistent with some observed similarities between the Briançonnais and the Provence-Corsica-Sardinia upper Paleozoic and Mesozoic stratigraphic sequences.

\section{The Oligocene revolution: westward extrusion and formation of the arc}

\subsection{Deformation in the External Zone: Main Alpine, west-directed stacking (D3)}

The eastern part of the Dauphiné zone was underthrust eastwards beneath the Crustal Pennine Thrust from early Oligocene onwards (Simon-Labric et al., 2009). This is recorded by the dominantly top-to-the west intense shear in the footwall of the CPT at the eastern edge of the Pelvoux massif (Butler, 1992), and approximately $30^{\circ}$ diverging transport directions on both sides of the Pelvoux culmination are observed (fig. 5; Gamond, 1980; Tricart, 1980; Bürgisser \& Ford, 1998). This demonstrates the occurrence of basement uplift in the Pelvoux area prior to the D3 westward transport of Internal Nappes over it, due to cumulative effects of D1 and D2 basement thickening. The change in orientation of shortening is documented in the footwall of the CPT by the tectonic overprint by deformation D3, which produced interference structures with the previous shortening episodes because of its different orientation.

To the north of the Pelvoux massif, a change in transport directions of thin-skinned thrust sheets from N-NW to W-NW or west is described (Bravard, 1982; Ceriani et al., 2001). Complicated 3D structures due to a near $90^{\circ}$ change in shortening orientation, from approximately $\mathrm{N}-\mathrm{S}$ (D2) to approximately E-W (D3), reactivate E-W trending thrusts as strike-slip faults (Dumont et al., 2008). To the SE of the Pelvoux, a D2 northwestward 
directed recumbent fold involving the Late Eocene flysch (Grès du Champsaur fm.), the olistostrome and part of the Embrunais Nappes (Kerckhove et al., 1978) is affected by D3 westward folding, so that antiformal hinges are developed both within the reverse limb and within the correct way-up section. This occurs in the footwall of the Prapic thrust, which is kinematically linked with the WSW-ward propagation of shortening in front of the Crustal Pennine Thrust (Bürgisser \& Ford, 1998).

At a larger scale, the interplay between NS and EW shortening is documented by the structure of the Meije granitic dome, whose shape is not issued from a preserved Hercynian pluton but from an Alpine compressional interference: this is shown by similar bending of the boundary between the granitic core and the gneissic envelopes and of the peripheral basement-cover interface with its Triassic cover (fig. 4, top), thereby precluding any Hercynian origin for this structure. The Meije dome is a result of N-S "arching" in the hangingwall of the Meije thrust (D2) combined with E-W arching in the footwall of the Crustal Pennine Thrust (D3). This dome may be regarded a smaller scale version of the sub-circular Pelvoux massif (fig. 3). Some other domes occur in the sedimentary cover of the External Zone (fig. 5), which are likely related with the same D2/D3 interference.

\subsection{Renewed distribution of foreland basins during early Oligocene}

The distribution of the foreland basins in the southern Subalpine domain (External Zone of the Western Alps) changed completely during Early Oligocene times (Ford et al., 2006): The formation of the Digne nappe (fig. 2; fig. 5), corresponding to the previously subsiding flexural basin, led most of the Eocene-lowermost Oligocene, westward pinching out flysch deposits to be uplifted and eroded by a continental drainage pattern. Conversely, some continental or lacustrine, westward thickening depocenters developed in the proximal foreland of this nappe, over an area which was previously devoid of sedimentation. Only a narrow area at the hinge between these two domains shows the Eocene and Oligocene sedimentary sequences overlapping (Meckel et al., 1996), but generally with an erosional unconformity between both (fig. 10, top).

The early Oligocene sediments in the Barrême thrust-top basin recorded (i) a $\sim 90^{\circ}$ shift in sedimentary transport directions (Evans \& Mange-Rajetsky, 1991; Callec, 2001), and (ii) a change in source rocks: the Grès de Ville were fed in crystalline basement clasts from the south (Provence-Corsica-Sardinia continent) whereas the overlying Clumanc conglomerates were fed in non-metamorphic and HP-LT ocean-derived clasts from the rapidly exhuming Alpine wedge located to the east or the NE (Chauveau \& Lemoine, 1961; Evans \& MangeRajetsky, 1991; Morag et al., 2008). The latter source zone, subject to very active erosion, has been identified as beeing inherited from parts of the Eocene accretionnary wedge having suffered strong shortening and uplift in early Oligocene times (Bernet \& Tricart, 2011, in press; Schwartz et al., submitted). The sediments of the Tertiary Piedmont basin also recorded a tectono-sedimentary shift at the same time, which consist of a sharp erosional unconformity truncating highly deformed Alpine nappes, and which is overlain by coarse continental clastics starting from the Early Oligocene (Polino et al., 1991; Cibin et al., 2003; Carappa et al., 2004; Di Giulio et al., 2001; Maroni et al., 2002).

Some Oligocene syndepositional deformation criteria observed in the French southern Subalpine foreland indicate a westward propagation, clearly different from the Eocene flexural basin setting: (i) in the Barême thrust-top syncline, top-to-the west syndepositional folding occurred as early as $31 \mathrm{Ma}$ ago (Artoni \& Meckel, 1998 ; Callec, 2001) ; (ii) further north, westward to NW-ward directed thrusting occurred prior to or during the deposition of the Rupelian «Molasse Rouge » fm. in the Digne area (Esclangon thrust-sheet : Haccard et al., 1989) and in Faucon du Caire area (C, fig. 2; Roche Cline thrust sheets: Arnaud et al., 1978). A westward shift of depocenters is observed in Oligo-Miocene times both in the 
southern Subalpine chains (Couëffé \& Marindet, 2003) and in the Helvetic realms (Beck et al., 1998).

To sum up, the observed interplay between exhumation of the axial chain, deformation of the western foreland, erosion and sedimentation clearly shows the occurrence of a sharp change during Early Oligocene times with respect to the Eocene framework: subsidence inversions, changes in clastics provenance, changes in the trends of syn-depositional deformation and changes in the direction of displacements of facies and depocenters. The age of this event can be bracketed within a short time interval between the youngest deposits of the flexural flysch basin ( 31-32 Ma, fig. 6 and refs. herein) and the oldest infill in the thrust-top molasse basins ( 30-31 Ma; Artoni \& Meckel, 1998; Callec, 2001).

\subsection{The early Oligocene orogen}

The extensive Alpine litterature provides many evidences of dramatic changes in the central part of the Alpine orogen during early Oligocene times. Both the magmatic activity, the deep and shallow structures, the morphology and the kinematic/geodynamic setting in the whole Alpine realm are involved in this revolution: the igneous activity, including the emplacement of the Periadriatic plutons between 33 and 31 Ma (Müller et al., 2001), is regarded as a thermal consequence of slab breakoff in the Central Alps (von Blankenburg \& Davies, 1995). The Bergell Pluton emplacement postdates N-directed nappes stacking and it is coeval with the onset of dextral shear and thrusting along the Periadriatic line segments (Schmid et al., 1989, 1996; Müller et al., 2001 ; Handy et al., 2010). Contemporaneous calc-alkaline postcollisional volcanism is reported from the early Oligocene flysch sediments in the northwestern foreland (Vuagnat, 1985; Waibel, 1990; Ruffini et al., 1997).

A review of published kinematic data in the Internal and External zones (fig. 6, right part) shows how brutally the trends of stretching lineations and transport directions vary trough time. The anticlockwise rotation was pointed by Platt et al. (1989a), but one can see more precisely a sharp $\sim 90^{\circ}$ change close to the Eocene-Oligocene boundary. Contrary to the coupled migration of the orogen and of the foreland basin during the Eocene lithospheric flexion (fig. 6, central and left parts), this tectonic shift seems to have occurred more or less simultaneously over the whole Alpine realm. Before, the internal zones were dominated by north-directed transport, associated with "transverse" folds (Caby, 1973) i.e. E-W trending. Pervasive D1 transport lineations (Choukroune et al., 1986) have been re-arranged by arcuate bending during later episodes (Rosenbaum \& Lister, 2005). Afterwards, the renewed tectonic activity is marked by the activation of major, west directed crustal thrusts in the Western Alps during early Oligocene (Badertscher \& Burkhard, 1998; Tricart et al., 2000; Fügenschuh \& Schmid, 2003; Simon-Labric et al., 2009), which cross-cut the previous nappes stack. Coeval eastward underthrusting of the Pelvoux massif is dated 31-33 Ma (Simon-Labric et al., 2009). This is also coeval with the onset of dextral movement along the Insubric line.

This early Oligocene event is also detected through a strong elevation of the axial Alpine orogen, which is suspected considering the increase in sediment budget in the northern and western forelands (Kuhlemann, 2000; Kempf \& Pross, 2005; Morag et al. 2008; Bernet and Tricart, 2010) leading to basins overfill and to the transition from flysch to molasse sedimentation. An other evidence is provided by the onset of coarse sedimentation in Lombardy and Piedmont, interpreted as a consequence of rapid unroofing in Western and Central Alps (Giger \& Hurford, 1989; Carrapa et al., 2004). From early Oligocene onwards, one can observe a dramatic discrepancy between (i) the rapidly exhuming axial chain, now represented by the Internal Zones, with exhumation and canibalization of the Eocene flexural basin with its initial overload in the French foreland, and (ii) rapid burial affecting the previously exposed Eocene HP wedge in the Italian Piedmont (Bertotti et al., 2006). 
Apart from the Alpine orogen itself, the Early Oligocene also corresponds to the initiation of subsidence in the West European rift system (Merle \& Michon, 2001), of the Corsica-Sardinia rifting (Lacombe \& Jolivet, 2005), and to the onset of the Tyrrhenian-Apenninic dynamics (Vignaroli et al., 2009; Handy et al., 2010). The first-order geodynamic cause which can explain both these features and the kinematic re-organization of the Alpine chain is still debated, but an increasing influence of the deep-seated mantle dynamics in the Mediterranean area is suspected (Faccenna et al., 2004).

\section{Discussion and conclusion}

The central and southern parts of the External Western Alps show evidence of several interfering shortening episodes during Alpine convergence. The present Pelvoux large-scale dome probably initiated over a basement ridge perpendicular to the present chain, i.e. W-E, and the southern Subalpine Meso-Cenozoic cover shows basin-and-swell structures (Remollon and Barrot domes, Embrun and Barcelonnette nappe windows; figs. 2 and 7) which result from interference between shortening events of varied orientations. Such interferences were up to now regarded as superposed effects of the dynamics of the Iberian and Adriatic plates, the former beeing responsible for Pyrenean-Provence deformations and the latter for Alpine episodes. However, we observe that part of N-S to NW-SE shortening in the southern foreland of the western Alpine arc actually relates to the early stages of the Adria-Europe collision, because it post-dates the onset of flexural loading of the European foreland by the Austro-Alpine wedge. Top-to-the northwest direction of propagation of the collisional thrust stack during the Eocene-earliest Oligocene time span (fig. 12) is documented by both near-surface evidence in the Paleogene flexural basin, such as synsedimentary folding, gravity sliding and submarine slope scar, and upper crustal deformation in the Dauphiné external basement. During the same period, HP-LT deformation within the palaeo-accretionnary prism occurred mainly in a northward propagating setting, as documented by published kinematic data from the internal arc (fig. 6, right). The diachroneity of high-pressure ages within the Briançonnais part of the subducted plate (fig. 6, middle) is best explained by a continental subduction regime spanning the entire Eocene, that is coeval with the flexural basin propagation. Considering this long lasting north- to NW-directed early Alpine kinematics, the elements which were involved in the accretionnary wedge, such as the Briançonnais continental margin fragments, have to be restored to the SE of future location of the western Alpine arc (fig. 13A). This is consistent with a palaeogeographic location of the Briançonnais domain to the east of the Iberia-Sardinia-Corsica microplate (e.g. Stampfli et al., 1998, 2002).

A complete renewal of the tectonic setting ocurred close to the Eocene-Oligocene boundary, initiating a mature stage of collision with westward escape of the Internal Nappes stack. According to many authors (Ziegler, 1989; Stampfli et al., 2002; Collombet et al., 2002; Rosenbaum \& Lister, 2005; Ford et al., 2006; Molli, 2008), the formation of the western Alpine arc occurred mainly after Eocene times, that is during this mature stage of collision with lateral extrusion. The deep part of the paleo-accretionnary wedge, having migrated northwards during the previous, continental subduction stage, was then cross-cut and thrust westwards over the emerged proximal part of the flexural basin, allowing a metamorphic rocks provenance for the synorogenic sediments during the Early Oligocene, a scenario which is summarized in fig. 12 and 13. According to us, and following Ford et al. (2006), this scenario provides the best explanation for the two-stages deformation history and interference structures observed in the external zone.

The Oligocene westward escape of the Internal Alps indenter was kinematically linked with the dextral motion along the Insubric fault to the north (Schmid et al., 1987) and with an expected conjugate sinistral shear zone to the south, from which the recent "Stura couloir" 
(Giglia et al., 1996) could derive. The lithospheric scale indenter is cored by Adriatic lithospheric mantle of the Ivrea body (Lardeaux et al., 2006). Thus, from the Early Oligocene onwards (fig. 13D), the northern part of Adria was translated westwards, indenting the accretionnary buildup derived from the previous continental subduction stage in between the western Alpine foreland and the uplifted western limit of the Adriatic lithosphere. In front of the Ivrea indenter, the "Piemont Schistes lustrés" fossil accretionnary wedge therefore suffered E-W ductile to brittle extensional shear during exhumation and tilting (Schwartz et al., 2009).

This two-stages model enlights the discrepancy between the present structure of recent "hypercollision" dynamics of the Western Alpine arc on the one hand, and the partly strikeslip continental subduction belt developped previously on the western edge of the northwardmoving Adriatic microplate (Ricou \& Siddans, 1986), on the other. The initiation of the arc would have been localised at the western termination of the Eocene flexural basin (fig. 13B and 13C). The Adria upper plate, responsible for flexural loading, did not extend westwards farther than the present location of the Ligurian Alps (fig. 13B and 13C), involving the occurrence of a major N-S sinistral transform boundary that we propose to name Western Adria Transform Zone (WATZ; fig. 13A). Considering the interpretations of Durand-Delga \& Rossi (2002), Faccenna et al. (2004) or Vignaroli et al. (2008), the longitudinal location of this boundary corresponded with a subduction polarity reversal of the Tethyan oceanic lithosphere, from NW-dipping beneath the Iberia-Sardinia-Corsica block to SE-dipping beneath Adria. As initially proposed by Ricou \& Siddans (1986), such a sinistral transform boundary allowed the Briançonnais domain to be detached from the Corsica-Provence realm and transported northwards. The northward propagation of Adria along this boundary produced initial thrusting of the oceanic accretionary wedge (so-called Piedmont Schistes lustrés) over the distal European margin, namely the Piedmont and internal Briançonnais domains, then the gradual involvement of Briançonnais fragments in the Tethyan subduction zone, contemporaneously with the closure of the Valais ocean further north (Handy et al., 2010). This northward motion of Adria provided the superposition of Adriatic and European lithospheric mantles, a duplication which is well documented in the Western Alps (Lardeaux et al., 2006).

The Oligocene Western Alpine evolution resulted primarily in the combined effects of two related dynamics: (i) westward indentation (combined with anticlockwise rotation; Channel, 1996) of previously uplifted Adriatic lithospheric mantle to the north (Ivrea body), and (ii) SE- to E-directed incipient Apenninic thrusting to the south, probably driven by slab roll-back beneath the Corsica-Sardinia-Provence realm suffering back-arc extension (Faccenna et al., 2004). The contrasting evolution of these two domains led to strain partitioning and the necessary development of strike-slip boundaries (Giglia et al., 1996; Malusa et al., 2009). The Ivrea body, which has been extensively investigated using geophysical methods (Roure et al., 1996; Schreiber et al, 2009 and refs. herein) and which outcrops at the western termination of the Southern Alps (Siegesmund et al., 2008), is an Adriatic lithospheric mantle and crustal fragment overthrusting the European Moho. The lower crustal section yielded Eocene ZFT ages (Siegesmund et al., 2008) which mark the N-directed thrusting stage (Handy et al., 1999) over the oceanic (Sesia) and continental European crust (Briançonnais) during the continental subduction stage. The western boundary of the Ivrea body, corresponding to lithospheric mantle, trends approximately N-S beneath the southern part of the Western Alpine arc (Waldhauser et al., 2002; Kissling et al., 2006; Lardeaux et al., 2006), that is in strong discrepancy with the present arc shape. We propose that this $\mathrm{N}-\mathrm{S}$ boundary which appears roughly rectilinear at $\sim 15 \mathrm{~km}$ depth (Vernant et al., 2002; Schreiber et al., 2010) could be a relict of the western transform boundary of Adria during northward Eocene drift (WATZ, fig. 13). The westward motion of this presumably inherited Adria indenter was accomodated by 
dextral shear along the Periadriatic line as soon as earliest Oligocene (Schmid et al., 1987; Handy et al., 2005), with possibly a conjugate sinistral shear zone to the south (Giglia et al., 1996). It produced fast exhumation of the Eocene paleo-accretionnary wedge, together with a dramatic increase in altitude and erosion rates. This exhumation is recorded within the lower Oligocene molasse basins on both sides of the renewed relief, sourced from high-pressure metamorphic rocks and oceanic mélanges of various metamorphic grades. The curvature of the arc was progressively acquired, producing radial spreading of transport lineations (Choukroune et al., 1986; Platt et al., 1989b; Lickorish et al., 2002) and southward increasing counter-clockwise rotations of internal units (Collombet et al., 2002). The southern part of the arc now cross-cuts perpendicularly the palaeo-accretionary wedge. The effects of Oligocene indentation were enhanced at the southern termination of the arc by the onset of CorsicaSardinia rifting (Guennoc et al., 2000) due to rollback of the NW-ward subducted Tethyan lithosphere (Faccenna et al., 2004; Jolivet et al., 2009).

The driving mechanism which produced this sharp change in the mode of accomodation of Africa-Europe convergence in the Alps, from continental subduction to collision with lateral extrusion, is still debated. There is little evidence for any change in relative motion between Africa and Europe (Dewey et al., 1989; Rosenbaum et al., 2002) but a motion change is recorded by Adria $35 \mathrm{Ma}$ ago (e.g. Handy et al., 2010). This renewal in Alpine kinematics must have been enhanced by the change of the subduction polarity from SE to NW in the Ligurian oceanic domain (Rosenbaum et al., 2002; Michard et al., 2006; Handy et al., 2010) and by the subsequent E-directed rollback of the eastern Ligurian oceanic domain and the incipient Mediterranean dynamics.

\section{Aknowledgements:}

This work was supported by the Agence Nationale pour la Recherche grant «ERD-Alps ». L. Jolivet and an anonymous reviewer are gratefully aknowledged for reviewing the manuscript.

\section{References}

Agard P., Jolivet L. \& Goffé B. (2001). Tectonometamorphic evolution of the Schistes Lustrés complex : implications for the exhumation of the HP and UHP rocks in the western Alps. Bull. Soc. Géol. France, 172, pp. 617-636.

Amaudric du Chaffaut S. (1982). Les unités alpines à la marge orientale du massif cristallin corse. Doctorate Thesis, Trav. Lab. Géologie Ecole Normale Supérieure, 15, Paris, 133p.

Arnaud H., Gidon M. \& Pairis J.L. (1978). Dislocations synsédimentaires du socle et déformations ultérieures de la couverture : l'exemple des chaînons subalpins au NE de Sisteron. C. R. Acad. Sc. Paris, 287, p. 787-790.

Artoni A. \& Meckel L.D. (1998). History and deformation rates of a thrust sheet top basin ; the Barrême basin, western Alps, SE France. Geol. Soc. London Spec. Publication n ${ }^{\circ} 134$, p. 213-237.

Aubourg C., Rochette P., Stéphan J.F., Popoff M. \& Chabert-Pelline C. (1999). The magnetic fabric of weakly deformed Late Jurassic shales from the southern subalpine chains (French Alps) : evidence for SW-directed tectonic transport direction. Tectonophysics, 307, pp. 15-31.

Authemayou C. (2002). Géométrie tridimentionnelle et tectonique de raccourcissement Nord-Sud dans le Massif du Pelvoux. Unpublished DEA, Université Joseph Fourier, Grenoble, 36p.

Badertscher N. \& Burkhard M., 1998. Inversion alpine du graben Permo-Carbonifère de Salvan-Dorénaz et sa relation avec le chevauchement de la nappe de Morcles sus-jacente. Eclogae Geol. Helv., 91, p. 359-373.

Badoux H. \& Weidmann M. (1963). Sur l'âge des Flyschs à Helminthoïdes des Préalpes Romandes et Chablaisiennes. Eclogae Geol. Helv., 56, p. 513-528.

Barbier R., Barféty J.C., Bocquet A., Bordet P., Le Fort P., Meloux J., Mouterde R., Pêcher A. \& Petiteville M. (1973). Carte géologique de la France au 1/50000è, feuille La Grave. Bur. Rech. Geol. Min., Orléans.

Barféty, J.C. 1988: Le Jurassique dauphinois entre Durance et Rhône. Etude stratigraphique et géodynamique. Documents du Bureau de Recherches géologiques et minières, Orléans, 131, 655 pp.

Barféty J.C. \& Gidon M., 1983. La stratigraphie et la structure de la couverture dauphinoise au Sud de Bourg d'Oisans. Leurs relations avec les déformations synsédimentaires jurassiques. Géologie alpine, 59, p. 5-32.

Barféty J.C., Tricart P. \& Jeudy De Grissac C. (1992). La quatrième écaille près de Briançon (Alpes françaises) : un olistostrome précurseur de l'orogenèse pennique éocène. C. R. Acad. Sc. Paris, 314, pp. 71-76.

Baudin T., Marquer D. \& Persoz F. (1993). Basement-cover relationships in the Tambo nappe (Central Alps, Switzerland) : geometry, structure and kinematics. Jour. Struct. Geology, 15, 543-553.

Berger J.P. \& Bousquet R. (2008). Subduction-related metamorphism in the Alps: review of isotopic ages based on petrology and their geodynamic consequences. Geol. Soc. London Spec. Publication n²298, p. 117-144. 
Berggren W.A., Kent D.V., Swisher C.C. \& Aubry M.P. (1995). A revised Cenozoic geochronology and chronostratigraphy. In : Berggren W.A., Kent D.V., Aubry M.P. \& Hardenbol J. (eds.) : Geochronology, time scale and global stratigraphic correlations. SEPM Special Publication 54, 129-212.

Bernet M. \& Tricart P. (in press). The Oligocene orogenic pulse in the Southern Penninic Arc (Western Alps): structural, sedimentary and thermochronological constraints. Bull. Soc. Géol. Fr.

Bertotti G., Mosca P., Juez J., Polino R. \& Dunai T. (2006). Oligocene to present kilometres scale subsidence and exhumation of the Ligurian Alps and the Tertiary Piedmont Basin (NW Italy) revealed by apatite (U-Th)/He thermochronology: correlation with regional tectonics. Terra Nova, 18, p. 18-25.

Bigot-Cormier F., Poupeau G. \& Sosson M. (2000). Dénudations différentielles du massif cristallin externe Alpin de l'Argentera (Sud-Est de la France) révélées par thermochronologie traces de fission (apatites, zircons). C. R. Acad. Sc. Paris, 330, 363-370.

Bigot-Cormier F., Sosson M., Poupeau G., Stéphan J.F. \& Labrin E. (2006). The denudation history of the Argentera Alpine External Crystalline Massif (Western Alps, France-Italy) : an overview from the analysis of fission tracks in apatites and zircons. Geodynamica Acta, 19, p. 455-473.

Bogdanoff S., Michard A., Mansour M. \& Poupeau G. (2000). Apatite fission track analysis in the Argentera massif : evidence of contrasting denudation rates in the External Crystalline Massifs of the Western Alps. Terra Nova, 12, 117125.

Bouroullec R., Cartwright J.A., Johnson H.D., Lansigu C., Quémener J.M. \& Savanier D. (2004). Syndepositional faulting in the Grès d'Annot Formation, SE France: high-resolution kinematic analysis and stratigraphic response to growth faulting. Geol. Soc. London Spec. Publication n²21, p. 241-265.

Bousquet R., Goffé B., Vidal O., Oberhänsli R. \& Patriat M. (2002). The tectono-metamorphic history of the Valaisan domain from the Western to the Central Alps : new constraints on the evolution of the Alps. GSA Bulletin, 114, p. 207225.

Bousquet R., Oberhänsli R., Goffe B., Wiederkehr M., Koller F., Schmid S., Schuster R., Engi M., Berger A. \& Martinotti G. (2008). Metamorphism of metasediments at the scale of an orogen: a key to the Tertiary geodynamic evolution of the Alps. Geol. Soc. London Spec. Publication n²98, p. 393-411.

Bravard C. (1982). Données nouvelles sur le stratigraphie et la tectonique de la zones des Aiguilles d'Arves au nord du col du Lautaret. Géologie Alpine, Grenoble, 58, p. 5-13.

Bravard C. \& Gidon M. (1979). La structure du revers oriental du Massif du Pelvoux: Observations et interprétations nouvelles. Géologie alpine, t.55, p. 23-33.

Broucke O., Guillocheau F., Robin C., Joseph P. \& Calassou S. (2004). The influence of syndepositional basin floor deformation on the geometry of turbiditic sandstones: a reinterpretation of the Cote de L'Ane area (SanguiniereRestefonds sub-Basin, Gres d'Annot, Late Eocene, France). Geol. Soc. London Spec. Publ., 221, p. 203-222.

Bucher S., Ulardic C., Bousquet R., Ceriani S., Fügenschuh B., Gouffon Y. \& Schmid S. (2004). Tectonic evolution of the Briançonnais units along a transect (ECORS-CROP) through the Italian-French Western Alps. Eclogae Geol. Helv., 97, pp. 321-345.

Bürgisser J. \& Ford M. (1998). Overthrust shear deformation of a foreland basin; structural studies south-east of the Pelvoux massif, SE France. Jour. Struct. Geol., 20, p. 1455-1475.

Butler R.W.H. (1992). Thrust zone kinematics in a basement-cover imbricate stack : Eastern Pelvoux massif, French Alps. Jour. Struct. Geol., 14, p. 29-40.

Butler R.W.H \& McCaffrey W.D. (2004). Nature of thrust zones in deep water sand-shale sequences: outcrop examples from the Champsaur sandstones of SE France. Mar. Petr. Geol., 21, p. 911-921.

Caby R. (1973). Les plis transversaux dans les Alpes occidentales : implications pour la genèse de la chaîne alpine. Bull. Soc. Géol. France, 15, pp. 624-634.

Callec Y. (2001). La déformation synsédimentaire des bassins paléogènes de l'arc de Castellane (Annot, Barrême, SaintAntonin). Mémoire Sciences de la Terre, Ecole des Mines de Paris, $n^{\circ}$ 43, 349p.

Callec Y. (2004). The turbidite fill of the Annot sub-basin (SE France) : a sequence stratigraphy approach. In : Joseph P. \& Lomas S.A. (Eds.), 2004, Deep water sedimentation in the Alpine basin of SE France. Geol. Soc. Spec. Publication $\mathrm{n}^{\circ}$ 221,pp. 111-135.

Campredon R. (1977). Les formations paléogènes des Alpes maritimes franco-italiennes. Memoire H. S. Soc. Geol. France, 199p.

Campredon R. \& Giannerini G. (1982). Le synclinal de St Antonin (arc de Castellane, Chaînes subalpines méridionales); un exemple de bassin soumis à une déformation compressive permanente depuis 1'Eocène supérieur. Géologie Alpine, Grenoble, 58, p. 15-20.

Capitanio F.A. \& Goes S. (2006). Mesozoic spreading kinematics: consequences for Cenozoic Central and Western Mediterranean subduction. Geophys. J. Int., 165, p. 804-816.

Caron C., Homewood P., Morel R. \& Stuijvenberg J. (1980). Témoins de la nappe du Gurnigel sur les Préalpes médianes : une confirmation de son origine ultrabriançonnaise. Bull. Soc. Fribourgeoise Sc. Nat., 69, p. 64-79.

Carrapa B., Di Giulio A. \& Wijbrans J. (2004). The early stages of the Alpine collision : an image derived from the upper Eocene-lower Oligocene record in the Alps-Apennines junction area. Sedimentary Geology, 171, p. 181-203.

Carry N. (2007). De la subduction continentale à l'exhumation dans les Alpes penniques. PhD Thesis, University of Rennes, $307 \mathrm{p}$.

Ceriani, S., Fügenschuh, B. \& Schmidt, S., 2001. Multi-stage thrusting at the «Penninic Front» in the Western Alps between Mont Blanc and Pelvoux massifs. Geol. Rund., 90, p. 685-702.

Ceriani S. \& Schmid S., 2004. From N-S collision to WNW-directed post-collisional thrusting and folding : Structural study of the Frontal Penninic Units in Savoie (Western Alps, France). Eclogae Geol. Helv., 97, p. 347-369.

Channel J.E.T. (1996). Paleomagnetism and paleogeography of Adria. Geol. Soc. London Spec. Publ., 105, p. 119-132. 
Chauveau J.C. \& Lemoine M. (1961). Contribution à l'étude géologique du synclinal tertiaire de Barrême (moitié nord). Bull . Serv. Carte géol. France, 58, p. 287-318.

Chevalier F., Guiraud M., Garcia J.P., Dommergues J.L., Quesne D., Allemand P. \& Dumont T. (2003). Calculating the longterm displacement rates of a normal fault from the high-resolution stratigraphic record (early Tethyan rifting, French Alps). Terra Nova 15, 410-416.

Choukroune P., Ballevre M., Cobbold P., Gautier Y., Merle O. \& Vuichard J.P. (1986). Deformation and motion in the Western Alpine arc. Tectonics, 5, p. 215-226.

Cibin U., Di Giulio A. \& Martelli L. (2003). Oligocene-Early Miocene tectonic evolution of the northern Apennines (northwestern Italy) traced through provenance of piggy-back basin fill successions. Geol. Soc. London Spec. Publ. $\mathrm{N}^{\circ} 208$, p. 269-287.

Cliff R.A., Barnicoat A.C. \& Inger S. (1998). Early Tertiary eclogite facies metamorphism in the Monviso Ophiolite. J. Metamorphic Geol., 16, p. 447-455.

Collombet M., Thomas J.C., Chauvin A., Tricart P., Bouillin J.P. \& Gratier J.P. (2002). Counterclockwise rotation of the western Alps since the Oligocene: New insights from paleomagnetic data. Tectonics, DOI 10.1029/2001TC901016.

Corsini M., Ruffet G. \& Caby R. (2004). Alpine and late Hercynian geochronological constraints in the Argentera massif (Western Alps). Eclogae Geol. Helv., 97, p. 3-15.

Couëffé R. \& Maridet O. (2003). Découverte de deux gisements à micromammifères du Burdigalien supérieur dans la molasse du bassin de Digne (Alpes de Haute Provence, SE France) : implications stratigraphiques et tectoniques. Eclogae Geol. Helv., 96, p. 197-207.

Courel L. et al. (1984). Trias. In : Debrand-Passard S., Courbouleix S. \& Lienhardt M.J., Synthèse géologique du Sud-Est de la France, Mémoire Bur. Rech. Géol. Min. n 125, pp. 61-117.

Crespo-Blanc A., Masson H., Sharp Z., Cosca M. \& Hunziker J. (1995). A stable and 40Ar-39Ar isotope study of a major thrust in the Helvetic nappes (Swiss Alps) : evidence for fluid flow and constraints on nappe kinematics. GSA Bulletin, 107, p. 1129-1144.

Dal Piaz G. (2001). Geology of the Monte Rosa massif: historical review and personal comments. Schweiz. Min. Petrogr. Mitt., 81, p. 275-303.

Debelmas J., Durozoy G., Kerckhove C., Monjuvent G., Mouterde R. \& Pêcher A. (1980). Notice de la carte géologique de la France au 1/50000è, feuille Orcières. Bur. Rech. Géol. Min., Orléans, 27p.

De Graciansky P.C., Roberts D.G. \& Tricart P. (2010). - The Western Alps, from rift to passive margin to orogenic belt. An integrated geoscience overview. Development in earth surface processes, Elsevier, 14, 429 p.

Dewey J.F., Helman M.L., Turco E., Hutton D.H.W. \& Knott S.D. (1989). Kinematics of the western Mediterranean. IN : Coward M.P., Dietrich D. \& Park R.G. (eds.), Alpine Tectonics, Geol. Soc. Spec. Publication n45, pp. 265-283.

Dèzes P., Schmid S. \& Ziegler P.A. (2004). Evolution of the European Cenozoic Rift System : interaction of the Alpine and Pyrenean orogens with their foreland lithosphere. Tectonophysics, 389, pp. 1-33.

Di Giulio A., Carrapa B., Fantoni R., Gorla L. \& Valdisturlo A. (2001). Middle Eocene to Early Miocene sedimentary evolution of the Lombardian segment of the South Alpine foredeep (Italy). Int. Jour. Earth Sciences (Geol. Rundsch.), 90, pp. 534-548.

Dommergues J.L., Guiffra A., Dumont T. \& Chevalier F. (in press). La Lumachelle à Cardinia (Bivalves) et Alsatites (Ammonites) du "Revers de Cote Dure" dans l'Hettangien de la couverture sédimentaire du Massif du Rochail (Oisans, Isère, France). Revue de Paléobiologie, Genève.

Duchêne S., Blichert-Toft J., Luais B., Télouk P., Lardeaux J.M. \& Albarède F. (1997). The Lu-Hf dating of garnets and the ages of the Alpine high-pressure metamorphism. Nature, 367, p. 586-589.

Du Fornel E., Joseph P., Desaubliaux G., Eschard R., Guillocheau F., Lerat O., Muller C., Ravenne C. \& Sztrakos K. (2004). The southern Grès d'Annot outcrops (French Alps) : an attempt at regional correlation. In : Joseph P. \& Lomas S.A. (Eds.), 2004, Deep water sedimentation in the Alpine basin of SE France. Geol. Soc. Spec. Publication n ${ }^{\circ} 221$, pp. 137160.

Dumont T. (1998). Sea-Level changes and early rifting of a European Tethyan margin in the western Alps and Southeastern France. In: de Graciansky P.C., Hardenbol J., Jacquin T. \& Vail P.R. (Eds): Mesozoïc and Cenozoic sequence stratigraphy of European Basins. Society of Economic Petrologists and Mineralogists, Special Publication 60, 623-642.

Dumont T., Champagnac J.D., Crouzet C. \& Rochat P. (2008). Multistage shortening in the Dauphiné zone (French Alps): the record of Alpine collision and implications for pre-Alpine restoration. Swiss Jour. Geosc., 101, p. 89-110.

Dumont T., Simon-Labric T., Authemayou C. \& Heymes T. (in press). Lateral termination of the north-directed Alpine orogeny and onset of westward escape in the Western Alpine arc: structural and sedimentary evidence from the external zone. Tectonics, doi:10.1029/2010TC002836, in press.

Durand-Delga M. \& Rossi P. (2002). About the Ligurian-Piemontese Ocean on the transect Corsica-Apennines. C. R. Geosciences, 334, p. 227-228.

Egal E. (1992). Structure and tectonic evolution of the external zone of Alpine Corsica. Jour. Struc. Geol., 14, pp. 1215-1228.

Engi M., Scherrer N.C. \& Burri T. (2001). Metamorphic evolution of pelitic rocks of the Monte Rosa nappe: Constraints from petrology and simple grain monazite age data. Scwiez. Min. Petrogr. Mitt., 81, p. 305-328.

Euzen T., Joseph P., Du Fornel E . \& Lesur S. (2004). Three-dimensional stratigraphic modelling of the Gres d'Annot system, Eocene-Oligocene, SE France. Geol. Soc. London Spec. Publ., 221, p. 161-180.

Evans M.J. \& Eliott T. (1999). Evolution of a thrust-sheet-top basin : the Tertiary Barrême Basin, Alpes de Haute Provence, France. Geol. Soc. America Bull., 111, pp. 1617-1643. Springer, Berlin, p. 185-206.

Evans M.J. \& Mange-Rajetsky M.A. (1991). The provenance of sediments in the Barrême thrust-top basin, Haute Provence, France. Geol. Soc. Spec. Publication n57, p. 323-342.

Faccenna C., Piromallo C., Crespo-Blanc A., Jolivet L. \& Rossetti F. (2004). Lateral slab deformation and the origin of the western Mediterranean arcs. Tectonics, 23, TC1012, $21 \mathrm{p}$. 
Fischer H. \& Villa I.M. (1990). Erste K/Ar- und (super 40)Ar/ (super 39)Ar- Hornblende-Mineralalter des TaveyannazSandstein. Schweitz. Mineral. Petrol. Mitt., 70, 73-75.

Ford M. (1996). Kinematics and geometry of early Alpine, basement involved folds, SW Pelvoux Massif, SE France. Eclogae Geol. Helv., 89, 269-295.

Ford M., Duchêne S., Gasquet D. \& Vanderhaeghe O., 2006. Two-phase orogenic convergence in the external and internal SW Alps. Jour. Geol. Soc. London, 163, p. 1-12.

Ford M. \& Lickorish W.H. (2004). Foreland basin evolution around the western Alpine Arc. In : Joseph P. \& Lomas S.A. (Eds.) : Deep-water sedimentation in the Alpine basin of SE France : new perspectives on the Grès d'Annot and related systems. Geological Society, London, Spec. Publ n²21, p. 39-63.

Ford M., Lickorish W.H. \& Kuznir N.J. (1999). Tertiary foreland sedimentation in the Southern Subalpine Chains, SE France: a geodynamic appraisal. Basin Research, 11, p. 315-336.

Freeman S.R., Butler R.W., Cliff R.A., Inger S. \& Barnicoat A.C. (1998). Deformation migration in an orogen-scale zone array : an example from the Basal Briançonnais Trust, internal Franco-Italian Alps. Geol. Mag., 135, pp. 349-367.

Freeman S.R., Inger S., Butler R.W. \& Cliff R.A. (1997). Dating deformation using Rb-Sr in white mica : greenschist-facies deformation ages from Entrelor shear zone, Italian Alps. Tectonics, 16, 57-76.

Froitzheim N., Schmid S.M. \& Conti P. (1994). Repeated change from crustal shortening to orogenparallel extension in the Austroalpine units of Graubunden. Eclogae geol. Helv. 87/2: 559612 (1994).

Fügenschuh B. \& Schmid S., 2003. Late stages of deformation and exhumation of an orogen constrained by fission-track data : a case study in the Western Alps. GSA Bulletin, 115, p. 1425-1440.

Gamond J.F. (1980). - Direction de déplacement et linéation : cas de la couverture sédimentaire dauphinoise orientale. Bull. Soc. géol. France 1984, (7), 22, p. 429-436.

Gebauer D., 1999. Alpine geochronology of the Central and Western Alps : new constraints for a complex geodynamic evolution. Schweiz. Mineral. Petrogr. Mitt., 79, p. 191-208.

Gidon M., Buffet G., Bonhomme M., Montjuvent G., Fourneaux J.C. \& Mouterde R. (1980). Carte géologique de la France au 1/50000è, feuille 845, St Bonnet. Bur. Rech. Geol. Min.

Gidon M. \& Pairis J.L. (1980). Nouvelles données sur la structure des écailles de Soleil Boeuf (bordure sud du massif du Pelvoux). Bull. Bur. Rech. Geol. Min., 1, p. 35-41.

Giger M. \& Hurford A.J., 1989. Tertiary intrusives of the Central Alps : their Tertiary uplift, erosion, redeposition and burial in the south-alpine foreland. Eclogae Geol. Helv., 82, pp. 857-866.

Giglia G., Capponi G., Crispini L \& Piazza M. (1996). Dynamics and seismotectonics of the West-Alpine arc. Tectonophysics, 267, p. 143-175.

Gratier J.P., Ménard G. \& Arpin R., 1989. Strain-displacement compatibility and restoration of the Chaînes Subalpines of the western Alps. IN : Coward M.P., Dietrich D. \& Park R.G. (eds.), Alpine Tectonics. Spec. Pub. No 45, pp. 65-81.

Guardia P. \& Ivaldi J.P. (1987). Contrôle tectonique de la sédimentation paléogène sur le bord méridional du massif de l’Argentera (Alpes Maritimes). Géologie Alpine, Grenoble, mém. H.S. nº 13, pp. 343-356.

Gubler-Wahl, Y. (1928). La nappe de l’Ubaye au sud de la vallée de Barcelonnette. Thèse, Paris, 201p.

Guellec S., Mugnier J.L., Tardy M. \& Roure F. (1990). Neogene evolution of the western Alpine foreland in the light of Ecors data and balanced cross-section. IN : Mem. Soc. Géol. France n 156, pp. 165-184.

Guennoc P., Gorini C. \& Mauffret A. (2000). Histoire géologique du Golfe du Lion et cartographie du rift oligo-aquitanien et de la surface messinienne. Géologie de la France, 3, pp. 67-97.

Guerrot C. \& Debon F. (2000). U-Pb zircon dating of two contrasting Late Variscan plutonic suites from the Pelvoux massif (French Western Alps). Schweitz Min. Petr. Mitt. 80, p. 249-256.

Guillot S., Di Paola S., Ménot R.P., Ledru P., Spalla M.I., Gosso G. \& Schwartz S. (2009). Suture zones and importance of strike-slip faulting for Variscan geodynamic reconstructions of the External Crystalline Massifs of the western Alps. Bull. Soc. Géol. France, 180, p. 483-500.

Gupta S. \& Allen P.A. (2000). Implications of foreland paleotopography for stratigraphic development in the Eocene distal Alpine foreland basin. GSA Bull., 112, p. 515-530.

Haccard D., Beaudouin B., Gigot P. \& Jorda M. (1989). Notice explicative de la carte géologique de France (1/50000), feuille La Javie (918). Bur. Rech. Géol. Min., Orléans, 152 p.

Handy M., Babist J., Wagner R., Rossenberg G. \& Konrad M. (2005). Decoupling and its relation to strain partitioning in continental lithosphere: insight from the Periadriatic fault system (European Alps). Geol. Soc. London Spec. Publ., 243, p. 249-276.

Handy M.R., Franz L., Heller F., Janott B. \& Zurbriggen R. (1999). Multistage accretion and exhumation of the continental crust (Ivrea crustal section, southern Alps, northwestern Italy and southern Switzerland. Geol. Soc. Am. Bull., 103, p. 236-253.

Handy M., Schmid S.M., Bousquet R., Kissling E. \& Bernouilli D. (2010). Reconciling plate-tectonic reconstructions of Alpine Tethys with the geological-geophysical record of spreading and subduction in the Alps. Earth Sc. Rev., 102, 121158.

Hardenbol J., Thierry J., Farley M.B., Jacquin T., de Graciansky P.C. \& Vail P. (1998). Mesozoic and Cenozoic sequence stratigraphic framework of European basins. In : de Graciansky P.C., Hardenbol J., Jacquin T. \& Vail P. (Eds.), Mesozoic and Cenozoic sequence stratigraphy of European basins. Soc. Econ. Min. Petr. Spec. Publ., 60, p. 3-14.

Ivaldi J.P. (1987). Le Paléogène détritique marin du pays des Arves (Savoie): analyse par thermoluminescence et paléogéographie. Géologie Alpine, Grenoble, mém. H.S. n 13, pp. 343-356.

Jean S. (1985). Les grès d'Annot au NW du massif de l'Argentera-Mercantour. Unpublished PhD Thesis, University of Grenoble, 244p.

Jeanbourquin P. \& Goy-Eggenberger D. (1991). Mélanges suprahelvétiques : sédimentation et tectonique au front de la nappe de Morcles (Vaud, Suisse). Géologie Alpine, 67, p. 43-62. 
Jolivet L., Faccenna C. \& Piromallo C. (2009). From mantle to crust : stratching the Mediterranean. Earth Plan. Sci. Lett., 285, p. 198-209.

Joseph P. \& Lomas S. (2004). Deep-water sedimentation in the Alpine foreland basin of SE France: new perspectives on the Grès d'Annot. An introduction. Geol. Soc. London Spec. Publ., 221, p. 1-16.

Keller L.M., Hess M., Fügenschuh B. \& Schmid S. (2005). Structural and metamorphic evolution of the CamugheraMoncucco, Antrona and Monte Rosa units southwest of the Simplon line, Western Alps. Eclogae Geol. Helv., 98, p. 1949.

Keller L.M. \& Schmid S. (2001). On the kinematics of shearing near the top of the Monte Rosa nappe and the nature of the Furgg zone in the Val Loranco (Antrona valley, N. Italy) : tectonometamorphic and paleogeographical consequences. Schweiz. Min. Petrogr. Mitt., 81, p. 347-367.

Kempf O. \& Pfiffner O.A. (2004). Early Tertiary evolution of the North Alpine Foreland Basin of the Swiss Alps and adjoining areas. Basin Research, 16, p. 549-567.

Kempf O. \& Pross J. (2005). The lower marine to lower freshwater Molasse transition in the northern Alpine foreland basin (Oligocene ; central Switzerland-south Germany) : age and geodynamic implications. Int. J. Earth Sci., 94, p. 160-171.

Kerckhove C. (1964). Mise en évidence d'une série à caractère d' »olistostrome » au sommet des grès d'Annot (Nummulitique autochtone) sur le pourtour des nappes de l'Ubaye (Alpes franco-italiennes). C. R. Acad. Sc. Paris, 259, p. $4742-4745$.

Kerckhove C. (1969). La Zone du Flysch dans les nappes de l'Embrunais-Ubaye (Alpes occidentales). Géologie Alpine, Grenoble, 45, p. 5-204.

Kerckhove C. (1974). Notice explicative de la Carte géologique de France au 1/50000è, feuille Barcelonnette (895), Bur. Rech. Géol. Min., Orléans.

Kerckhove C., Cochonat P. \& Debelmas J. (1978). Tectonique du soubassement parautochtone des nappes de l'EmbrunaisUbaye sur leur bordure occidentale, du Drac au Verdon. Géologie Alpine, Grenoble, 54, pp. 67-82.

Kerckhove, C. \& Thouvenot, F. (2008). Notice explicative de la Carte géologique de France au 1/50 000è, feuille Allos (919), deuxième édition., Bur. Rech. Géol. Min., Orléans.

Kissling E., Schmid S., Lippitsch R., Ansorge J. \& Fügenschuh B. (2006). Lithosphere structure and tectonic evolution of the Alpine arc: new evidence from high-resolution teleseismic tomography. In: Gee D.G. \& Stephenson R.A. (eds.): European Lithosphere Dynamics. Geol. Soc. London Memoirs, 32, p. 129-145.

Kuhlemann J. (2000). Post-collisional sediment budget of circum-Alpine basins (Central Europe). Mem. Sci. Geol. Padova, 52, pp. 1-91.

Kurz W., Neubauer F. \& Genser J. (1996). Kinematics of Penninic nappes (Glockner Nappe and basement-cover nappes) in the Tauern Window (Eastern Alps, Austria) during subduction and Penninic-Austroalpine collision. Eclogae Geol. Helv., 89 , pp. 573-605.

Lacombe O. \& Jolivet L. (2005). Structural and kinematic relationships between Corsica and the Pyrenees-Provence domain at the time of the Pyrenean orogeny. Tectonics, 24, pp. 1-20.

Labaume P., Jolivet M., Souquière F. \& Chauvet A. (2008). Tectonic control on diagenesis in a foreland basin: combined petrologic and thermochronologic approaches in the Grès d'Annot basin (Late Eocene-Early Oligocene, French-Italian external Alps). Terra Nova, 20, p. 95-101.

Lahondère D., Rossi P. \& Lahondère J.C., 1999. Structuration alpine d'une marge continentale externe : le massif du Tenda (Haute-Corse). Implications géodynamiques au niveau de la transversale Corse-Apennins. Géologie de la France, 4, pp. $27-44$.

Lanteaume, M. (1990). Notice explicative de la Carte géologique de France au1/50 000è, feuille Viève-Tende (948). Bur. Rech. Géol. Min., Orléans, 129 p.

Lapen T.J., Johnson C.M., Baumgrtner L.P., Dal Piaz G.V., Skora S. \& Beard B.L., 2007a. Coupling of oceanic and continental crust during Eocene eclogite-facies metamorphism : evidence from the Monte Rosa nappe, Western Alps, Italy. Contributions to Mineralogy and Petrology, 153, p. 139-157.

Lapen T.J., Johnson C.M. \& Beard B.L., 2007b. Lu-Hf age and isotope systematics of the Dora Maira nappe, western Alps. Goldschmidt Conference Abstracts, 2007, A544.

Lardeaux J.M., Schwartz S., Tricart P., Paul A., Guillot S., Béthoux N. \& Masson F. (2006). A crustal-scale cross-section of the southwestern Alps combining geophysical and geological imagery. Terra Nova, 18(6), p. 412-422.

Lateltin O. 1 Müller D. (1987). Evolution paléogéographique du bassin des grès de Taveyannaz dans les Aravis (Haute Savoie) à la fin du Paléogène. Eclogae Geol. Helv., 80, pp. 127-140.

Le Bayon B. \& Ballèvre M. (2006). Deformation history of a subducted continental crust (Gran Paradiso, Western Alps) : continuing crustal shortening during exhumation. Jour. Struct. Geol., 28, p. 793-815.

Leloup P.H., Arnaud N., Sobel E.R. \& Lacassin R., 2005. Alpine thermal and structural evolution of the highest external cristalline massif : the Mont Blanc. Tectonics, 24, TC4002, $26 \mathrm{p}$.

Lemoine M., 1972. Rythme et modalité des plissements superposés dans les chaînes subalpines méridionales des Alpes occidentales françaises. Geol. Runschau, 61, pp. 975-1010.

Lemoine M., Bas T., Arnaud-Vanneau A., Arnaud H., Dumont T., Gidon M., Bourbon M., De Graciansky P.C., Rudckiewicz J.L., Megard-Galli J. \& Tricart P. (1986). - The continental margin of the Mesozoic Tethys in thé Western Alps. Marine and Petroleum Geology, Vol.3, August 86, p. 179-199.

Lemoine, M., Dardeau, G., Delpech, P.Y., Dumont, T., de Graciansky, P.C., Graham, R., Jolivet, L., Roberts, D. \& Tricart, P. 1989: Extension syn-rift et failles transformantes jurassiques dans les Alpes occidentales. C. R. Acad. Sc. Paris, 309, 1711-1716.

Lickorish W.H., Ford M., Bürgisser J. \& Cobbold P.R. (2002). Arcuate thrust systems in sandbox experiments: A comparison to the external arcs of the Western Alps. GSA Bulletin, 114, pp. 1089-1107. 
Lihou J.C. (1995). A new look at the Blattengratt unit of Eastern Switzerland : Early Tertiary foreland basin sediments from the South Helvetic realm. Eclogae Geol. Helv., 88, p. 91-114.

Malusà G.M., Polino R., Zattin M. (2009). Strain partitioning in the axial NW Alps since the Oligocene. Tectonics, 28, p. 126.

Malusà G.M., Polino R., Zattin M., Bigazzi G., Martin S. \& Piana F. (2005). Miocene to Present differential exhumation in the Western Alps : Insights from fission track thermochronology. Tectonics, 24, TC3004, 23p.

Markley M.J., Teyssier C., Cosca M.A., Caby R., Hunziker J.C. \& Sartori M. (1998). Alpine deformation and ${ }^{39} \mathrm{Ar}-{ }^{40} \mathrm{Ar}$ geochronology of synkinematic white mica in the Siviez-Mischabel Nappe; western Pennine Alps, Switzerland. Tectonics, 17, 407-425.

Marroni M., Feroni A.C., Di Biase D., Ottria G., Pandolfi L. \& Taini A. (2002). Polyphase folding at upper structural levels in the Borbera Valley (northern Apennines, Italy): implications for the tectonic evolution of the linkage area between Alps and Apennines. C. R. Géoscience, 334, p. 565-572.

Meckel L.D., Ford M. \& Bernouilli D . (1996). Tectonic and sedimentary evolution of the Dévoluy Basin, a remnant of the Tertiary western Alpine foreland basin, SE France. Géologie de la France, 2, pp. 3-26.

Meffan-Main S., Cliff R.A., Barnicoat A.C., Lombardo B. \& Compagnoni R. (2004). A Tertiary age for Alpine high-pressure metamorphism in the Gran Paradiso massif, Western Alps: a Rb-Sr microsampling study. Jour. Metam. Geology, 22, 267-281.

Mercier de Lépinay D. \& Feinberg H. (1982). L'olistostrome sommital des grès delphino-helvétiques dans la partie nordoccidentale du massif de Platé-Haut-Giffre (Haute Savoie, Alpes occidentales) : nature, âge et implications structurales. C. R. Acad. Sc. Paris, 294, pp. 1279-1284.

Merle O. et Brun J.P. (1981). La déformation polyphasée de la nappe du Parpaillon (Flysch à Helminthoïdes): un résultat de la déformation progressive asociée à une translation non rectiligne. C.R. Acad. Sc. Paris t.292, p. 343-346.

Merle O., Cobbold P.R. \& Schmid S. (1989). Tertiary kinematics in the Lepontine dome. IN : Coward M.P., Dietrich D. \& Park R.G. (eds.), Alpine Tectonics, Geol. Soc. Spec. Publication n45, pp. 113-134.

Merle O. \& Michon L. (2001). The formation of the West European rift : A new model as exemplified by the Massif Central area. Bull. Soc. Géol. Fr., 172, 213-221.

Michard A., Avigad D., Goffé B. \& Chopin Ch (2004). The high-pressure metamorphic front of the south Western Alps (Ubaye-Maira transect, France, Italy). Schweitz. Min. Petr. Mitt., 84, 215-235.

Michard A., Dumont T., Andreani L. \& Loget N. (2010). Cretaceous folding in the Dévoluy Mountains (Subalpine Chains, France): Gravity-driven detachment at the European paleomargin versus compressional event. Bull. Soc. géol. France., 180 , in press.

Michard, A., Chalouan, A., Feinberg, H., Goffé, B., Montigny, R., 2002. How does the Alpine belt end between Spain and Morocco? Bulletin. Société Géologique de France 173, 3-15.

Molli G. (2008). Northern Apennine-Corsica orogenic system: an updated overview. Geol. Soc. London, Special Publication, 298, p. 413-442.

Monié P. (1990). Preservation of Hercynian ${ }^{39} \mathrm{Ar}-{ }^{40} \mathrm{Ar}$ ages through high-pressure low-temperature Alpine metamorphism in the Western Alps. Eur. J. Mineral., 2, 343-361.

Morag N., Avigad D., Harlavan Y., McWilliams M. \& Michard A. (2008). Rapid exhumation and mountain building in the Western Alps: Petrology and 40Ar/ 39Ar geochronology of detritus from Tertiary basins of southeastern France. Tectonics, 27, p. 1-18.

Mosar J., Stampfli G. M. \& Girod F. (1996). Western Préalpes Médianes Romandes: Timing and structure. A review. Eclogae geol. Helv. 89, p. 389425.

Müller W., Prosser G., Mancktelow N., Villa I., Kelly S.P., Viola G. \& Oberli F. (2001). Geochronological constraints on the evolution of the Periadriatic Fault system (Alps). Int. J. Earth Sciences (Geol. Rundsch.), 90, pp. 623-653.

Nagel T.J., 2008. Tertiary subduction, collision and exhumation recorded in the Adula nappe, central Alps. Geol. Soc. London, Special Publication, 298, p. 365-392.

Padoa E. (1999). Les ophiolites du massif de l'Inzecca (Corse alpine): lithostratigraphie, structure géologique et évolution géodynamique. Géologie de la France, 3, p. 37-48.

Pairis J.L. (1988). Paléogène marin et structuration des Alpes occidentales françaises. Doctorate Thesis, Grenoble University, $501 \mathrm{p}$.

Pairis J.L., Campredon R., Charollais J. \& Kerckhove C. (1984). Paléogène, Alpes. In : Debrand-Passard S., Courbouleix S. \& Lienhardt M.J., Synthèse géologique du Sud-Est de la France, Mémoire Bur. Rech. Géol. Min. n 125, pp. 410-415.

Pairis J.L. \& Kerckhove C. (1987). Le flysch de St Clément (Haut Embrunais) : un paléoprisme d'accrétion nummulitique dans la zone subbriançonnaise. Géologie Alpine, mémoire H.S., 13, p. 371-378.

Parsy-Vincent A. (1974). Contribution à l'étude géologique de la partie SW de la Balagne sédimentaire (Corse). Unpublished $\mathrm{PhD}$ Thesis, Université Paul Sabatier, Toulouse, $101 \mathrm{p}$.

Pêcher A., Barféty J.C. \& Gidon M. (1992). Structures est-ouest anténummulitiques à la bordure orientale du massif des Ecrins-Pelvoux (Alpes françaises). Géologie Alpine, Grenoble, Série spéciale Résumés, 1, p. 72-73.

Platt J.P., Behrmann J.H., Cunningham P.C., Dewey J.F., Helman M., Parrish M., Shepley M.G., Wallis S. \& Weston P.J. (1989a). Kinematics of the Alpine arc and the motion history of Adria. Nature, 337, pp. 158-161.

Platt J.P., Lister G.S., Cunningham P., Weston P., Peel F., Baudin T. \& Dondey H. (1989b). Thrusting and backthrusting in the Briançonnais domain of the western Alps. In : Coward M.P., Dietrich D. \& Park R.G. (Eds.), Alpine Tectonics. Geol. Soc. Spec. Pub. $N^{\circ} 45$, pp. 135-152.

Polino R., Ruffini R. \& Ricci B. (1991). Le molasse terziarie della collina di Torino: relazioni con la cinematica alpina. Atti Tic. Sc. Terra, 34, p. 85-95.

Puigdefabregas C., Gjelberg J. \& Vaksdal M. (2004). The Gres d'Annot in the Annot syncline: outer basin-margin onlap and associated soft-sediment deformation. Geol. Soc. London Spec. Publ., 221, p. 367-388. 
Ravenne C., Vially R., Riche P. \& Trémolières P. (1987). Sédimentation et tectonique dans le bassin marin Eocène supérieurOligocène des Alpes du Sud. Rev. Institut Français du Pétrole, 42, pp. 529-553.

Reddy S.M., Wheeler J., Butler R.W.H., Cliff R.A., Freeman S., Inger S., Pickles C. \& Kelley S.P. (2003). Kinematic reworking and exhumation within the convergent Alpine orogen. Tectonophysics, 365, 77-102.

Ricou L.E. \& Siddans A.W.B. (1986). Collision tectonics in the Western Alps. IN : Collision tectonics, Coward M.P. \& Ries A.C. (Eds.), Geol. Soc. sp. publ., 19, p. 229-244.

Ring U., 1995. Horizontal contraction or horizontal extension? Heterogeneous Late Eocene and Early Oligocene general shearing during blueschist and greenschist facies metamorphism at the Pennine-Austroalpine boundary zone in the Western Alps. Geol. Rundsch., 84, 843-859.

Rosenbaum G. \& Lister G.S (2005). The Western Alps from the Jurassic to Oligocene: spatio-temporal constraints and evolutionary reconstructions. Earth-Sc. Rev., 69, p. 281-306.

Rosenbaum G., Lister G.S. \& Duboz C. (2002). Relative motion of Africa, Iberia and Europe durin the Alpine orogeny. Tectonophysics, 359, 117-129.

Roure F., Choukroune P. \& Polino R. (1996). Deep seismic reflection data and new insights on the bulk geometry of mountain ranges, C. R. Acad. Sci. Paris, 322(2a), 345-359.

Rubatto D., Gebauer D. \& Compagnoni R., 1999. Dating of eclogite-facies zircons : the age of Alpine metamorphism in the Sesia-Lanzo zone (Western Alps). Earth-Planet. Sci. Lett., 167, 141-158.

Rubatto D. \& Hermann J. (2001). Exhumation as fast as subduction ? Geology, 29, p. 3-6.

Ruffini R., Polino R., Callegari E., Hunziker J.C. \& Pfeifer H.R. (1997). Volcanic-rich turbidites of the Taveyanne sandstones from the Thônes syncline (Savoie, France) : records for a Tertiary postcollisional volcanism. Schweitz. Mineral. Petrogr. Mitt., 77, 161-174.

Sanchez G., Rolland Y., Jolivet M., Brichau S., Corsini M. \& Carter A. (2011a). Exhumation controlled by transcurrent tectonics: the Argentera-Mercantour massif (SW Alps). Terra Nova, 23, p. 116-126, DOI:10.1111/j.13653121.2011.00991.x

Sanchez G., Rolland Y., Schneider J., Corsini M., Oliot E., Goncalves P., Verati C., Lardeaux J.M. \& Marquer D. (2011b). Dating low temperature deformation by ${ }^{40} \mathrm{Ar} /{ }^{39} \mathrm{Ar}$ on white micas, insights from the Argentera-Mercantour massif (SW Alps). Lithos, DOI: 10.1016/j.lithos.2011.03.009

Schlunegger F. \& Willett S. (1999). Spatial and temporal variations in exhumation of the Central Swiss Alps and implications for denudation mechanisms. In : Geol. Soc. London Spec. Publ. N${ }^{\circ} 154$, Exhumation processes, pp. 157-179.

Schmid S.M., Aebli H.R., Heller F. \& Zingg A. (1989). The role of the Periadriatic Line in the tectonic evolution of the Alps. IN : Coward M.P., Dietrich D. \& Park R.G. (eds.), Alpine Tectonics, Geol. Soc. Spec. Publication n45, pp. 153-171.

Schmid S., Berger A., Davidson C., Giere R., Hermann J., Nievergelt P., Puschnig A.R. \& Rosenberg C. (1996). The Bergell pluton (Southern Switzerland, Northern Italy): Overview accompanying a geological-tectonic map of the intrusion and surrounding country rocks. Schweiz. Min. Petr. Mitt., 76, p. 329-355.

Schmid S.M. \& Kissling E. (2000). The arc of the western Alps in the light of geophysical data on deep crustal structure. Tectonics, 19, pp. 62-85.

Schmid S.M., Zingg A. \& Handy M. (1987). The kinematics of movements along the Insubric Line and the emplacement of the Ivrea Zone. Tectonophysics, 135, p. 47-66.

Schreiber D., Lardeaux J.M., Martelet G., Courrioux G. \& Guillen A. (2009). 3-D modelling of Alpine Mohos in Southwestern Alps. Geophys. Jour. Int., 180, p. 961-975.

Schwartz S., Guillot S., Tricart P., Bernet M., Jourdan S., Dumont T. \& Montagnac G. (submitted). Source tracing of detrital serpentinite in the Oligocene molasse deposits from Western Alps (Barrême basin): implications for relief formation in the Internal Zone. Geol. Mag.

Schwartz S., Lardeaux J.M., Tricart P., Guillot S. \& Labrin E. (2007). Diachronous exhumation of HP-LT metamorphic rocks from south-western Alps : evidence from fission-tracks analysis. Terra Nova, 19, p. 133-140.

Schwartz S., Tricart P., Lardeaux J.M., Guillot S. \& Vidal O. (2009). Late tectonic and metamorphic evolution of the Piedmont accretionary wedge (Queyras Schistes lustres, western Alps): Evidences for tilting during Alpine collision. Geol. Soc. America Bull., 121, p. 502-518.

Seno S., Dallagiovanna G. \& Vanossi, M. (2005). A kinematic evolutionary model for the Penninic sector of the Ligurian Alps. Int. J. Earth Sci., 94, p. 114-129.

Siegesmund S., Layer P., Dunkl I., Vollbrecht A., Steenken A., Wemmer K. \& Ahrendt H. (2008). Exhumation and deformation history of the lower crustal section of the Valstrona di Omegna in tne Ivrea Zone, southern Alps. Geol. Soc. London Spec. Publ., 298, p. 45-68.

Simon-Labric T., Rolland Y., Dumont T., Heymes T., Authemayou C., Corsini M. \& Fornari M. (2009). ${ }^{40} \mathrm{Ar} /{ }^{39} \mathrm{Ar}$ dating of Penninic Front tectonic displacement (W Alps) during the Lower Oligocene (31-34 Ma). Terra Nova, 21, p. 127-136.

Sinclair H.D., 1997. Tectonostratigraphic model for underfilled peripheral foreland basins : an Alpine perspective. G.S.A. Bulletin, 109, pp. 324-346.

Smith R. \& Joseph P. (2004). Onlap stratal architectures in the Gres d'Annot: geometric models and controlling factors. Geol. Soc. London Spec. Publ., 221, p. 389-399.

Stampfli G., Borel G., Marchant R. \& Mosar J. (2002). Western Alps geological constraints on western Tethyan reconstructions. In : Rosenbaum G. \& Lister G.S. (eds.), Reconstruction of the evolution of the Alpine-Himalayan orogen. Jour. Virtual Explorer, 7, p. 75-104.

Stampfli G., Mosar J., Marquer D. \& Marchant R. (1998). Subduction and obduction processes in the Swiss Alps. Tectonophysics, 296, p. 159-204.

Stanley D.J. (1980). The Saint-Antonin conglomerate in the Maritime Alps: A model for coarse sedimentation on a submarine slope. Smithsonian contrib. Mar. Sci., 5, p. 1-28.

Steck A. (1990). Une carte des zones de cisaillement ductile des Alpes centrales. Eclogae Geol. Helv., 83, p. 603-627. 
Steck A. (1998). The Maggia cross-fold: An enigmatic structure of the Lower Penninic nappes of the Lepontine Alps. Eclogae Geol. Helv., 91, p. 333-343.

Tapponnier P., (1977). Evolution tectonique du système alpin en Méditerrannée : poinçonnement et écrasement rigideplastique. Bull. Soc. Géol. France, 19, pp. 437-460.

Tempier C. (1987). Modèle nouveau de mise en place des structures provençales. Bull. Soc. Géol. France, 8, p. 1-8.

Tilton G.R., Schreyer W. \& Schertl H.P. (1991). Pb-Rb-Nd isotopic behaviour of deeply subducted crustal rocks from the Dora Maira Massif, Western Alps, Italy : what is the age of the ultrahigh-pressure metamorphism ? Contributions to Mineralogy and Petrology, 108, p. 22-33.

Tricart P. (1980). Tectoniques superposées dans les Alpes occidentales, au sud du Pelvoux. Evolution structurale d'une chaîne de collision. Thèse de Doctorat d'Etat, Strasbourg, 407 p.

Tricart, P. \& Schwartz, S. (2006). A north-south section across the Queyras Schistes lustrés (Piedmont zone, western Alps): Syn-collision refolding of a subduction wedge. Eclogae Geol. Helv., 99, p. 429-442.

Tricart, P., Schwartz, S., Sue, C., Poupeau, G. \& Lardeaux, J.M, 2000. La dénudation tectonique de la zone ultradauphinoise et l'inversion du front briançonnais au sud-est du Pelvoux (Alpes occidentales) : une dynamique miocène à actuelle. Bull. Soc. géol. France, 172, p. 49-58.

Varrone D. \& d'Atri A. (2007). Acervulinid macroid and rhodolith facies in the Eocene Nummulitic

Limestone of the Dauphinois Domain (Maritime Alps,Liguria,Italy). Swiss Jour. Geosci., 100, p. 503-515.

Vernant P., Masson F., Bayer R. \& Paul A. (2002). Sequential inversion of local earthquake traveltimes and gravity anomaly - the example of the western Alps. Geophys. J. Int., 150, p. 79-90.

Vernet J. (1966). Observations nouvelles sur le synclinal d'Ailefroide et les bordures du massif du Pelvoux en Vallouise. Trav. Lab. Géol. Grenoble, 42, p. 275-280.

Vialon P., Rochette P. \& Ménard G.(1989). Indentation and rotation in the western Alpine arc. IN : Coward M.P., Dietrich D. \& Park R.G. (eds.), Alpine Tectonics., Geol. Soc. London Spec. Pub., 45, pp. 329-338.

Vignaroli G., Faccenna C., Jolivet L., Piromallo C. \& Rossetti F. (2008). Subduction polarity reversal at the junction between the Western Alps and the Northern Apennines, Italy. Tectonophysics, 450, p. 34-50.

Vignaroli G., Faccenna C., Rossetti F. \& Jolivet L. (2009). Insights from the Apennines metamorphic complexes and their bearing on the kinematics evolution of the orogen. Geol. Soc. London Spec. Publ., 311, p. 235-256.

Von Blankenburg F. \& Davies J. H. (1995). Slab breakoff : a model for syncollisional magmatism and tectonics in the Alps. Tectonics, 14, p. 120-131.

Vuagnat M. (1985). Les grès de Taveyanne et roches similaires : vestiges d'une activité magmatique tardi-alpine. Mem. Soc. Géol. Ital., 26, pp. 39-53.

Waibel A.F. (1990). Sedimentology, petrographic variability and very-low-grade metamorphism of the Champsaur sandstone (Paleogene, Hautes Alpes, France). PHD Thesis, Geneva, 140p.

Waldhauser F., Lippitsch R., Kissling E. \& Ansorge J. (2002). High-resolution tomography of upper-mantle structure using an a priori three-dimensional crustal model. Geophys. Jour. Int., 150, p. 403-414.

Ziegler P.A. (1989). Geodynamic model for Alpine intra-plate compressional deformation in Western and Central Europe. Geol. Soc. London Spec. Publ., 44, p. 63-85.

Zimmermann R., Hammerschmidt K. \& Franz G. (1994). Eocene high pressure metamorphism in the Pennine units of the Tauern window (Eastern Alps) : evidence from 40Ar-39Ar dating and petrological investigations. Contr. Mineral. Petrol., 117, p. 175-186. 




\section{Figure 1}

Overall map of the Western Alps and their foreland.

CPT : Crustal Pennine Thrust, boundary between the External and Internal Zones.

Horizontal stripped areas: Internal Zones, made of metamorphic units displaced from the European tethyan margin, the Ligurian Tethys ocean and from the Adriatic margin.

Vertical stripped areas: early emplaced nappes, including units issued from the distal European passive margin (Briançonnais, Piedmont) and from the ocean floor (Helminthoid flyschs). P: Prealps; E: Embrunais-Ubaye nappes; L: Ligurian nappes. 


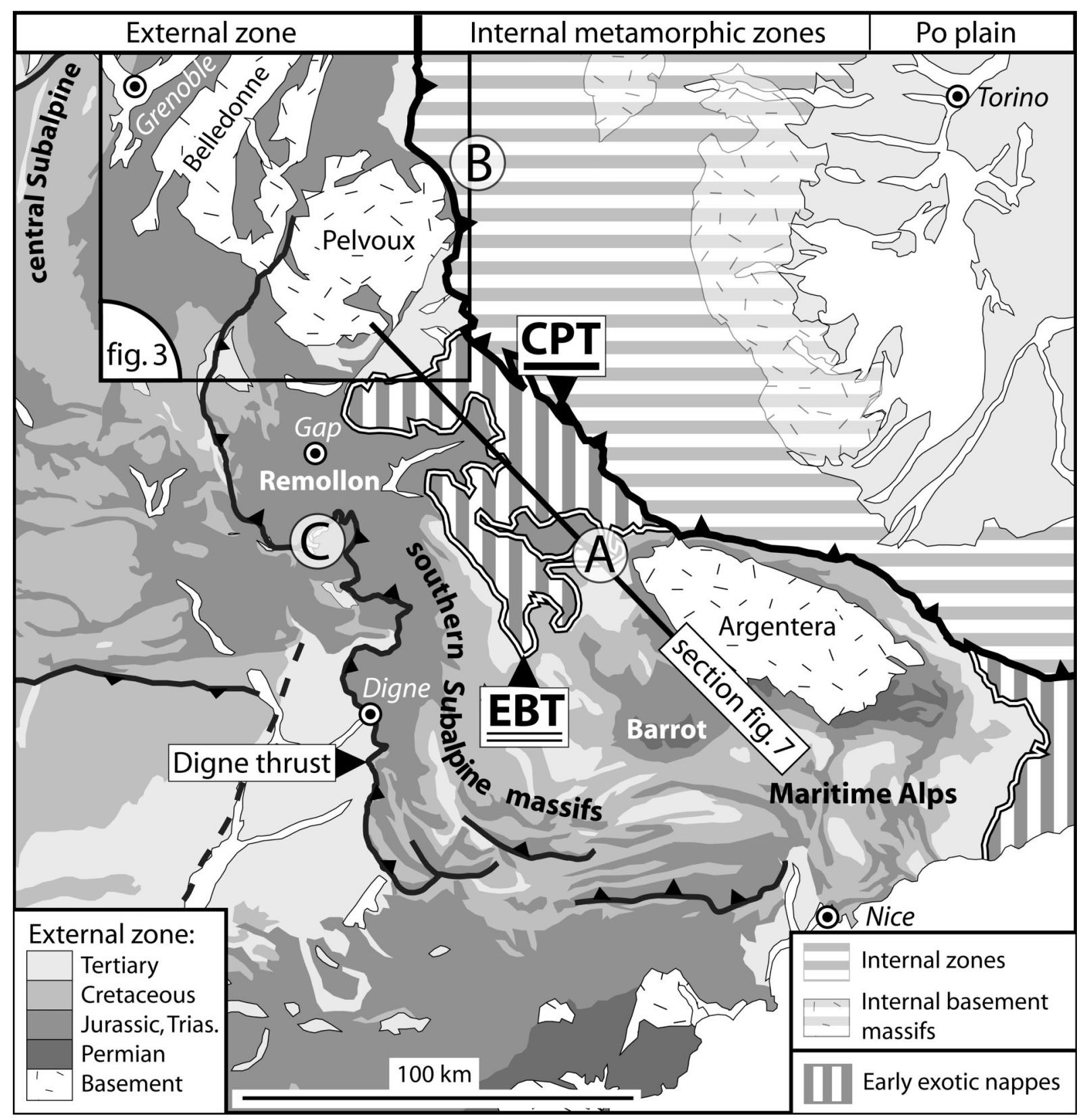

\section{Figure 2}

Detailed map of the Dauphiné, Provence, Southern Subalpine and Maritime Alps areas, with location of Figs. 3 and 7.

A: locality of Figs. 8, 9, 10 (bottom) and 11 (right). B: locality of Fig. 11 (left). C: locality of Fig. 10 (top). CPT: Crustal Pennine Thrust, sole of the Internal Nappes; EBT: Embrunais Basal Thrust, sole of the Embrunais Nappes.

Areas of interest (see text)-A: around Restefond pass (SE of Barcelonnette city); B: around the Galibier pass ( $\mathrm{N}$ of Brianc, on city); C: Faucon du Caire ( $\mathrm{S}$ of Gap city). 


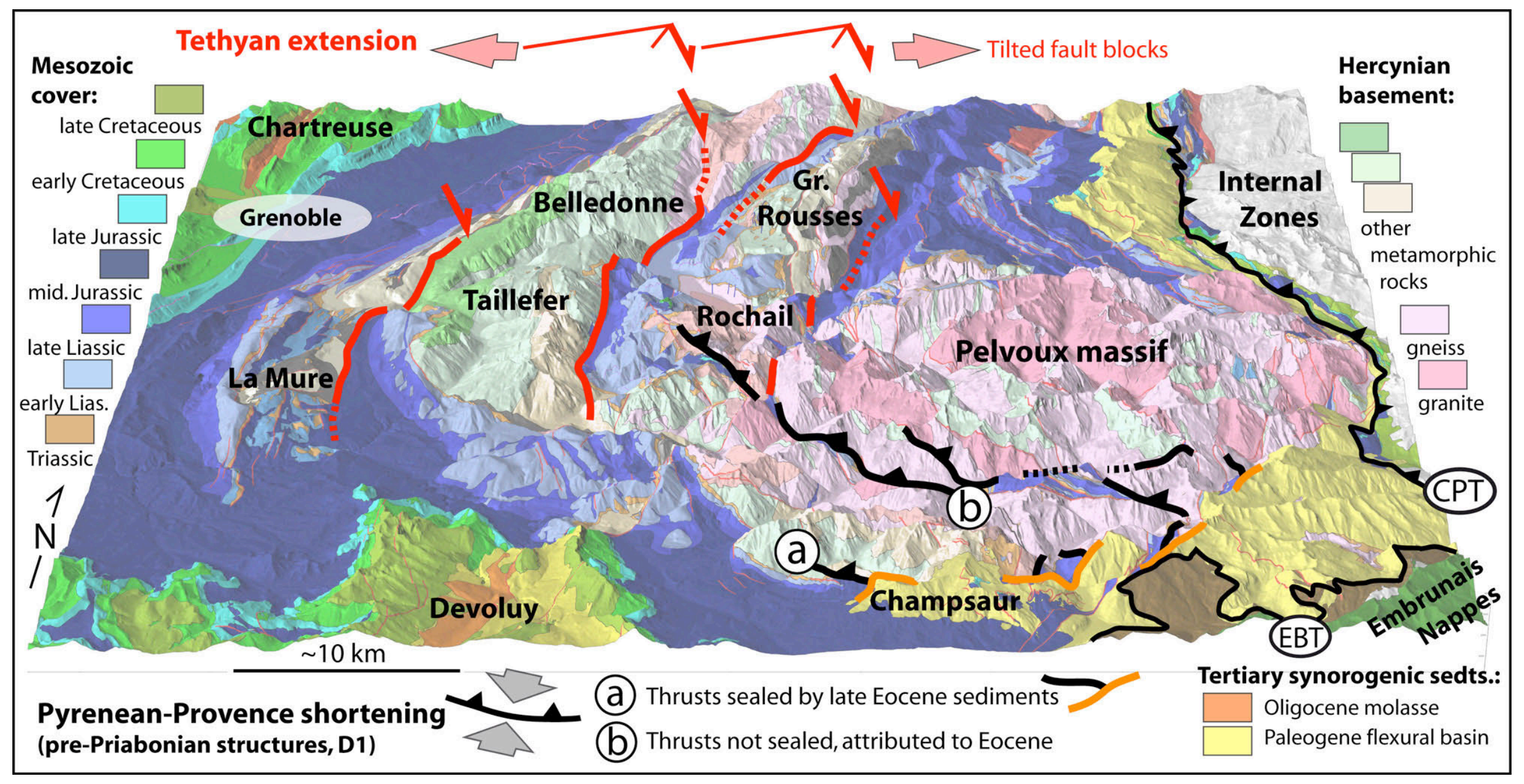

\section{Figure 3}

Tethyan and Pyrenean-Provence inheritance in the Dauphiné External massifs (area located on fig. 2): the NE-SW to NS orientation of the western Dauphiné massifs (Belledonne-Taillefer, Grandes Rousses-Rochail) corresponds to Tethyan tilted fault blocks (red) superimposed on the Hercynian fabric. Conversely, the Pelvoux massif has a sub-circular shape, its southern and southwestern boundaries beeing underlined by prePriabonian thrusts (black). 


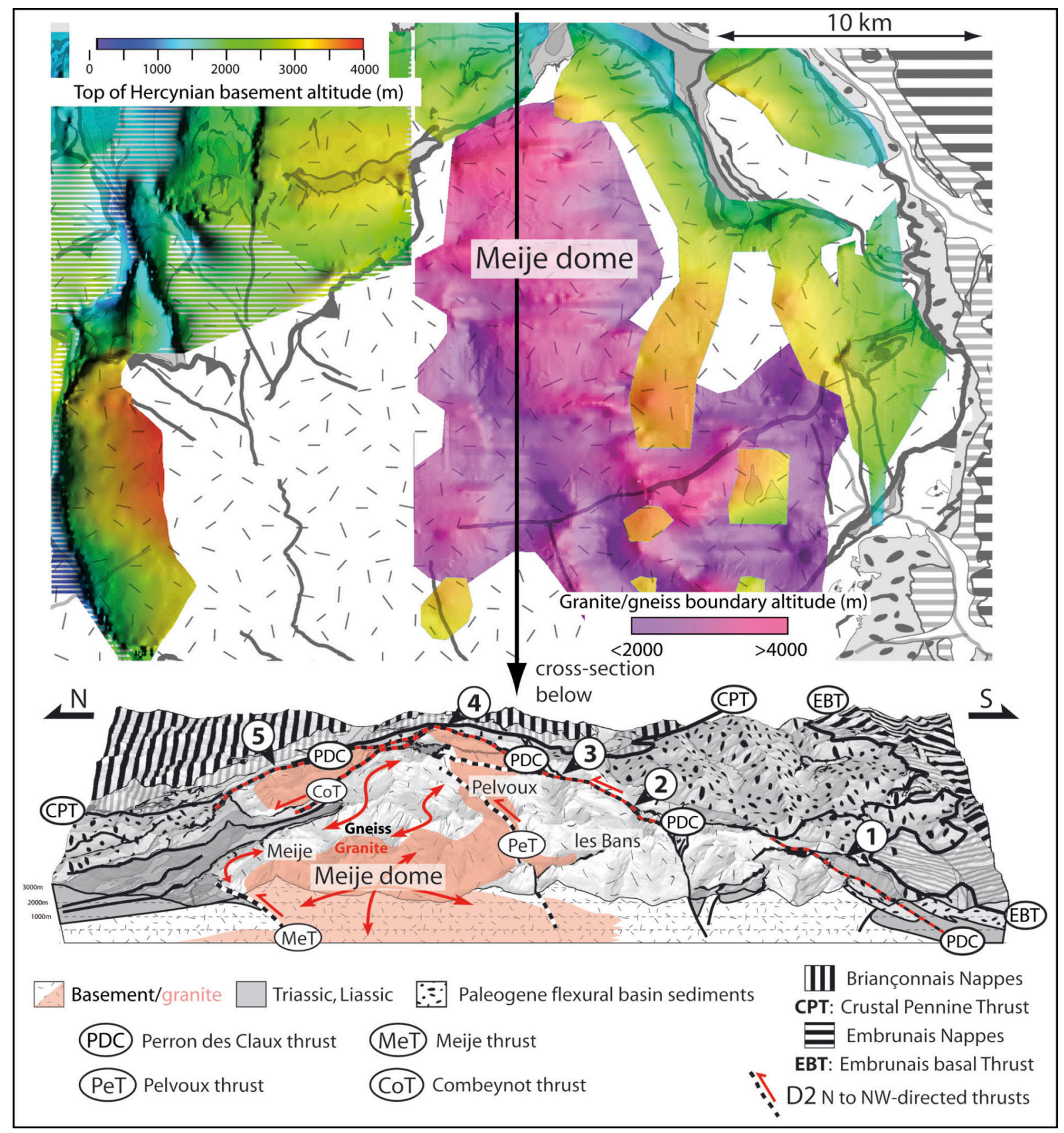

\section{Figure 4}

The Meije dome, an interference between NS (or NW-SE) and EW shortening in the Pelvoux external basement massif.

Upper part: 3D map of the basement/Mesozoic cover interface (rainbow shaded surface) and of the granite/gneiss interface (purple shaded surface) in the northern Pelvoux area. Despite the erosion of the former surface in the central part, both of them are clearly involved in the dome shape, which demonstrates that this structure is Alpine in age (post-Mesozoic).

Lower part: block diagram (looking to the East) and associated NS section across the Pelvoux massif and the Meije dome, with the main thrusts and localities cited in the text: 1- col de Méollion and Sommet Drouvet, north of Orcières ; 2- northern side of Les Bans valley (Onde river) ; 3- northern side of Ailefroide valley, between Ailefroide and Pelvoux villages ; 4upper Vallon de Chambran, SE of Rochers de l'Yret ; 5- from NE slopes of the Combeynot massif (Rochers de la Madeleine) to southern slopes of Crête de Chaillol (W of Lautaret pass). 


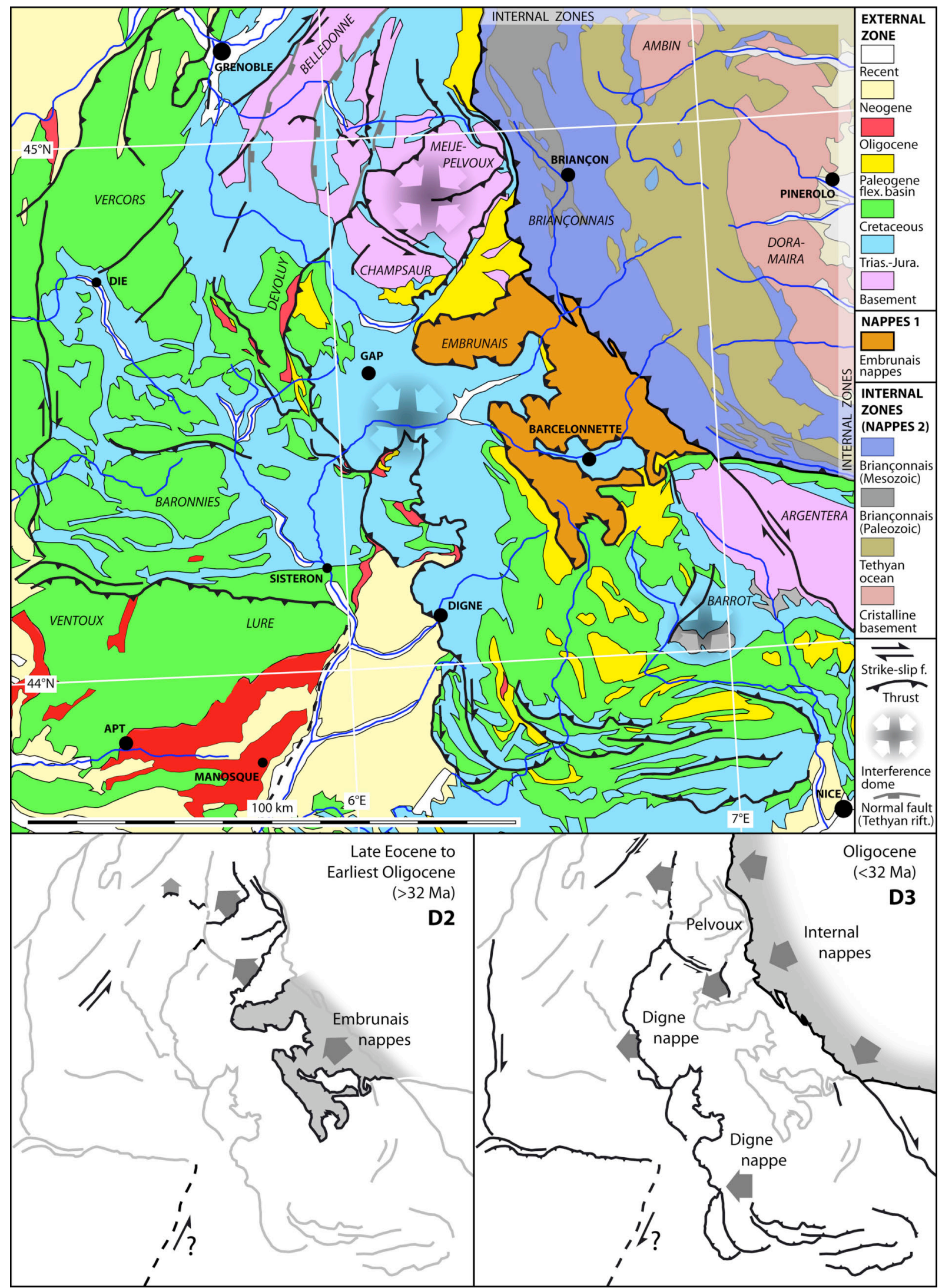

Figure 5: Structural sketch map from Dauphiné to Provence, and main faults and thrusts involved in the N-to NW-directed episode (D2) and in the W- to SW-directed episode (D3), respectively (cartoons in the lower part of the figure). 


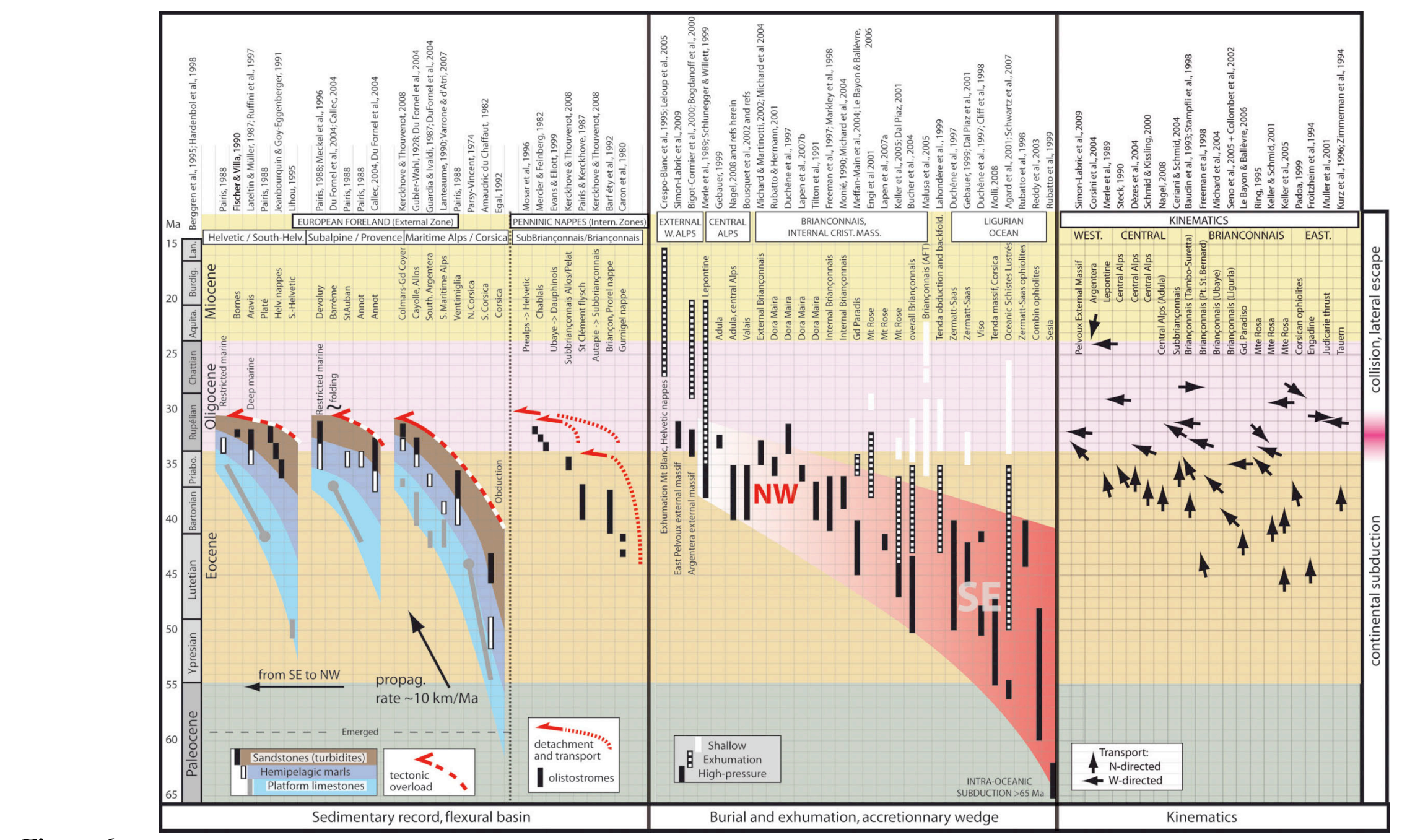

Figure 6

Chronostratigraphic litterature review comparing the sedimentary record of the Paleogene flexural basin of the Western Alps (left part), the metamorphic imprint of the European passive margin units involved in the Alpine orogen (central part) and their kinematic record (tectonic transport criteria, right part). The continental subduction regime, marked by the propagation of the flexural basin and by the diachronicity of the HP-LT metamorphism in the orogenic wedge, is associated with N-directed transport criteria. It ceased during early Oligocene, coeval with the re-orientation of kinematic indicators. 


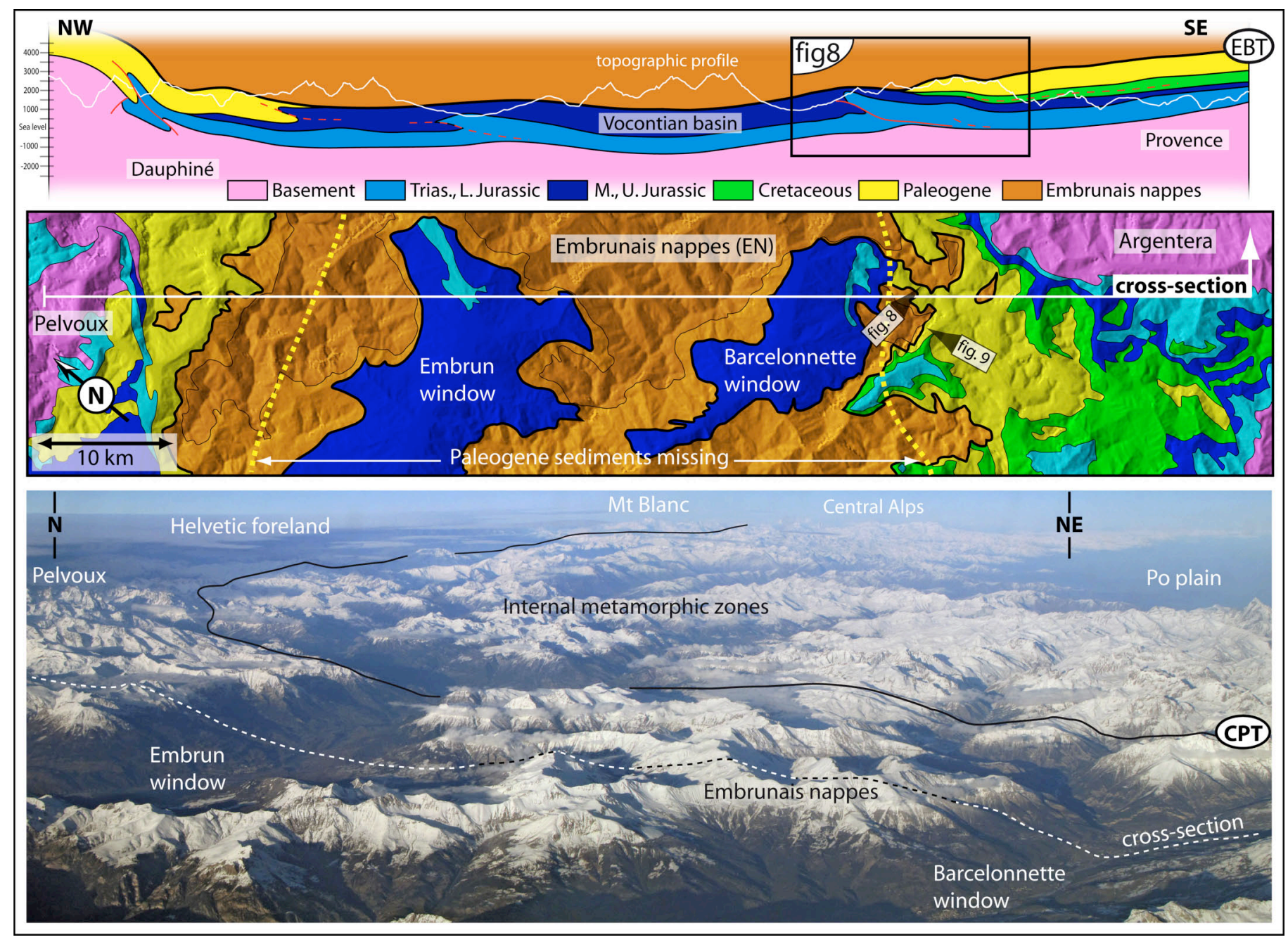

Figure 7: Upper part: NW-SE section across the external zone of the southern western Alps, from the southern Pelvoux to the Argentera massif (vertical exaggeration 2x). This profile is trending sub-parallel to the present Alpine orogen in the southern part of the western arc, but it crosscuts sub-perpendicularly the early Alpine structures (D2). The Paleogene series (yellow) are missing in the central part of the profile (area between the yellow dashed lines on the map) due to erosion before the emplacement of the Embrunais nappes (orange). This erosion, which occurred in submarine setting (see fig. 8 to 10), is regarded as the consequence of an incipient structural inversion of the Mesozoic Vocontian basin, whose thick series are now exposed in the Embrun and Barcelonnette tectonic windows.

Lower part: aerial photograph of the western Alpine arc from the SW: the Embrunais Nappes are underlined by snow in the foreground. 


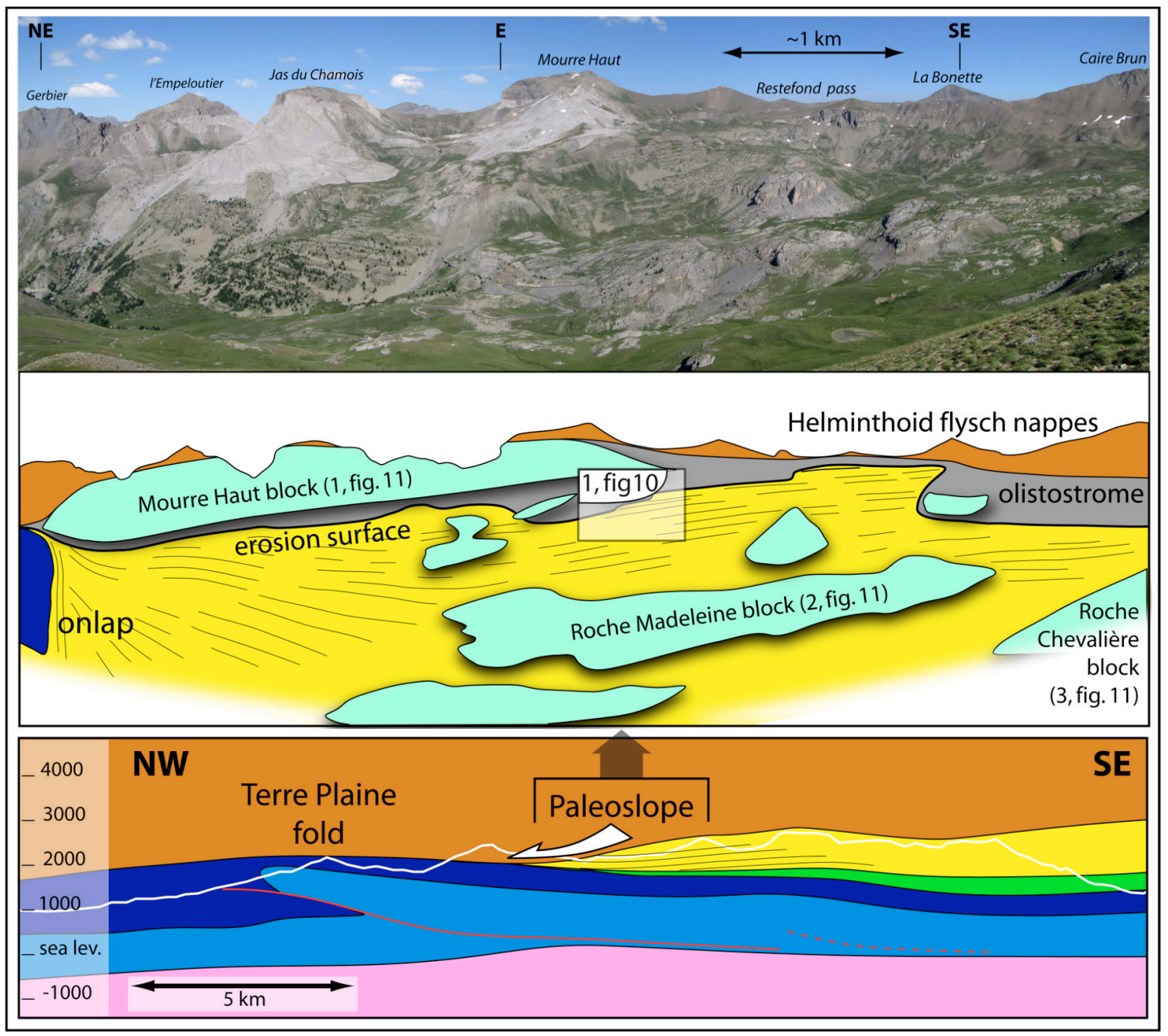

\section{Figure 8:}

The Restefond paleoslope, located to the SE of the Barcelonnette city (location Figs. 2 (A) and 7). Bottom: detail of the cross-section of Fig. 7(top) at the SE termination of the Barcelonnette window (same colors legend as Fig. 7). Both onlap and erosion of the Grès d'Annot fm. occurred over the hangingwall of the Terre Plaine fold-and-thrust structure, which was therefore active during Priabonian to earliest Oligocene times. Top and middle: panoramic view of the northern slopes of the Restefond pass, showing (i) the onlap of the Grès d'Annot sandstones over the tilted Globigerina hemipelagic marls near "cabanne de Clapouse" (left part of the picture), and (ii) the truncation of the Grès d'Annot stratification beneath the "Schistes à blocs" olistostrome layer (grey). The paleoslope resulting from this truncation is dipping northwestwards, that is oblique with respect to the panoramic view. Several hectometric to kilometric scale slided blocks are hanging over this paleoslope, which are issued from different domains (see text). The stratigraphic composition of these blocks is given in Fig. 11 (right). 


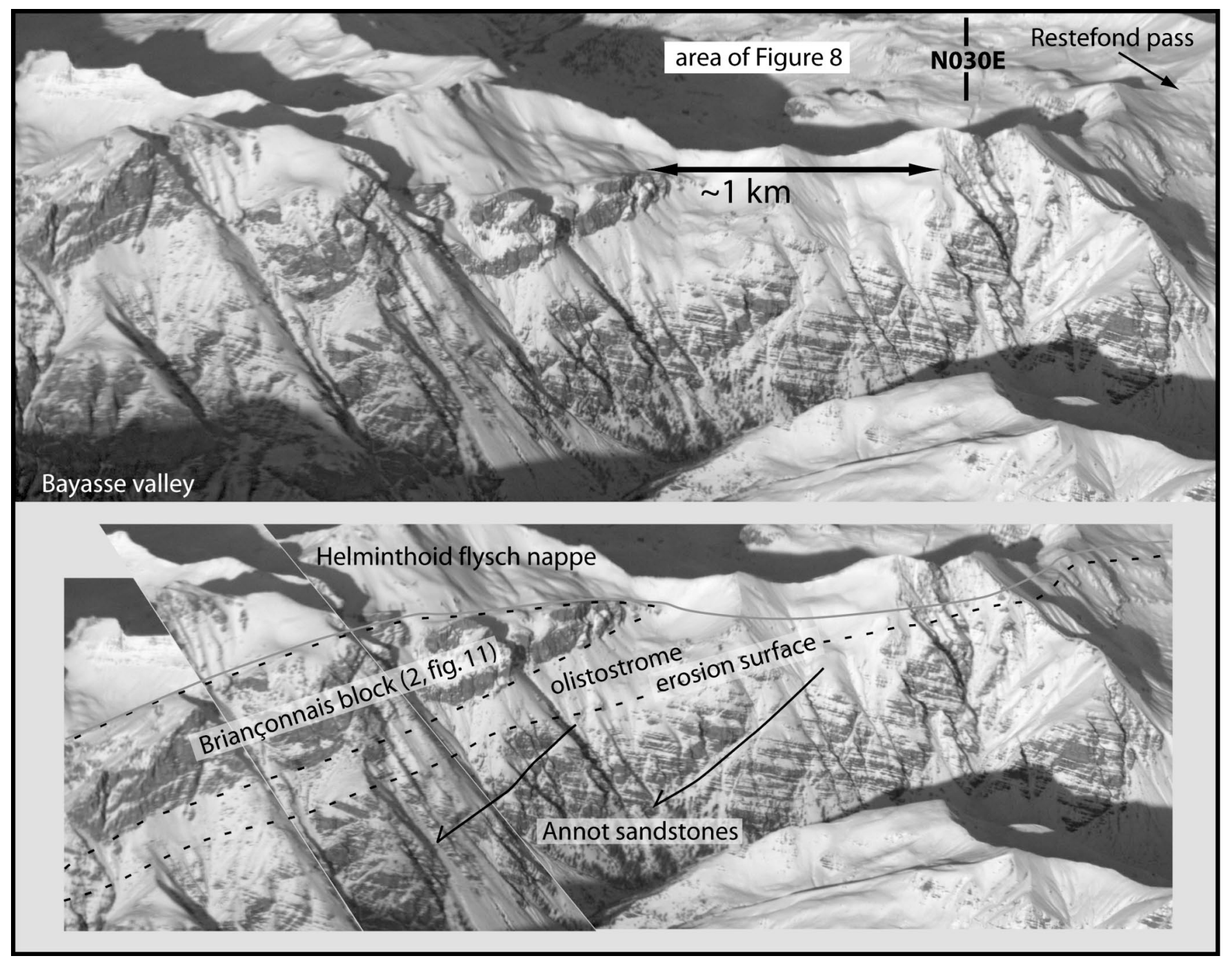

Figure 9:

Top: aerial photograph of the south-dipping "Mauvaise côte" cliff, located to the west of the Restefond pass. Bottom: same view with recent normal faulting restored (left part). This cliff truncates obliquely the submarine erosion surface which is presented in Fig. 8. The stratification of the Annot sandstone $\mathrm{fm}$. is enhanced by snow, showing a $20^{\circ}$ apparent angle with the erosion surface. 


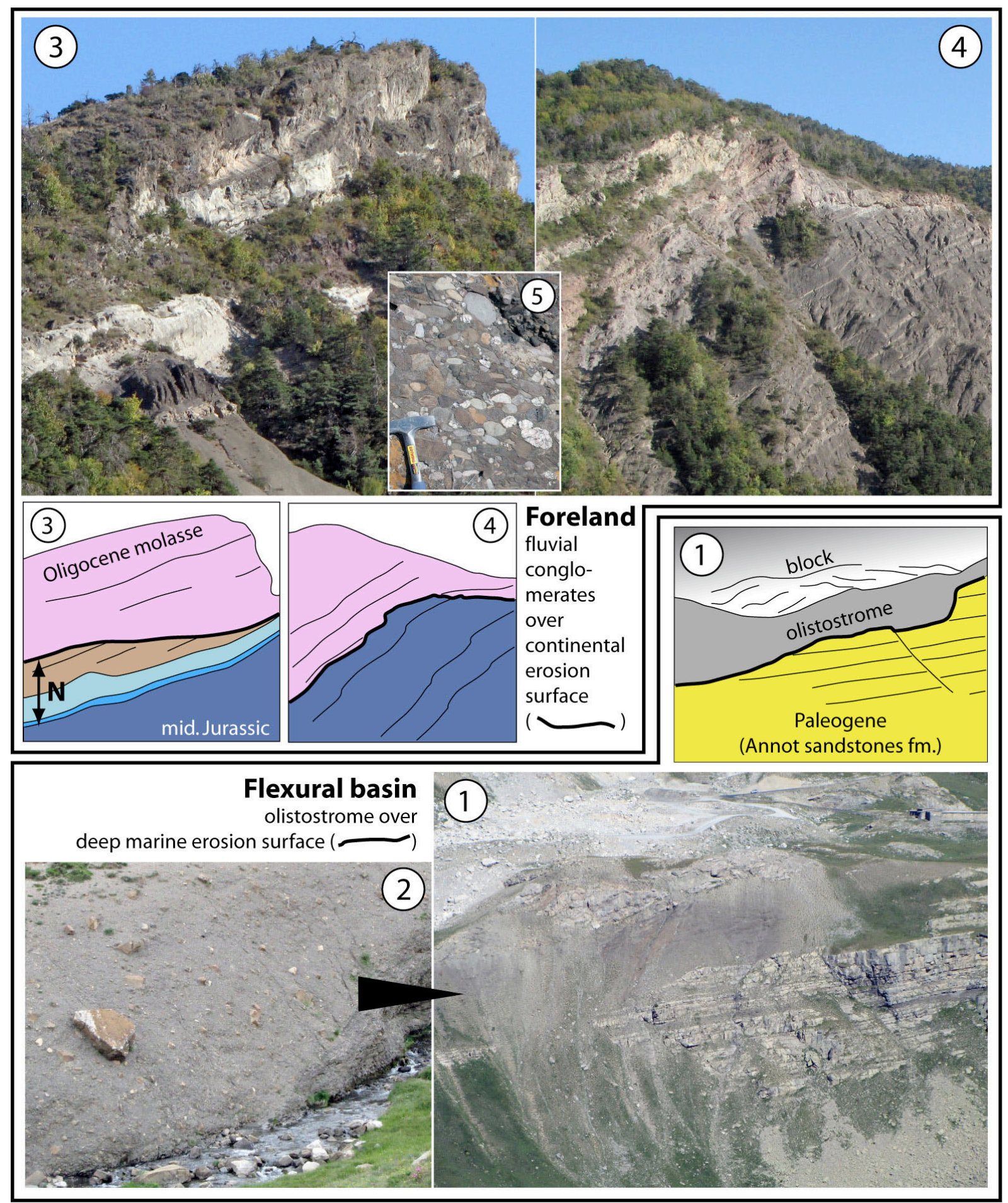

Figure 10: Outcrop views of the erosion surface which caps the sediments of the Late Eocene-Earliest Oligocene flexural basin (continental subduction stage):

1) In basinal setting (location A, fig. 2; outcrop located on fig. 8), the submarine erosion surface is covered by olistostrome deposits (2) dated of early Oligocene age in the Helvetic realm (Mercier de Lépinay \& Finberg, 1982) and by slided blocks (figs. 8, 9).

3,4 ) Towards the foreland (location $\mathrm{C}$, fig. 2), a rugged continental erosion surface truncates the late Eocene-early Oligocene succession ("Nummulitic", N) and is onlapped by the continental "Molasse Rouge" fm. (fluvial conglomerates, 5) of Oligocene age. Location of the outcrops: south of Faucon du Caire (3: ravin de la Bouchouse; 4: ravin de la Bouse). 


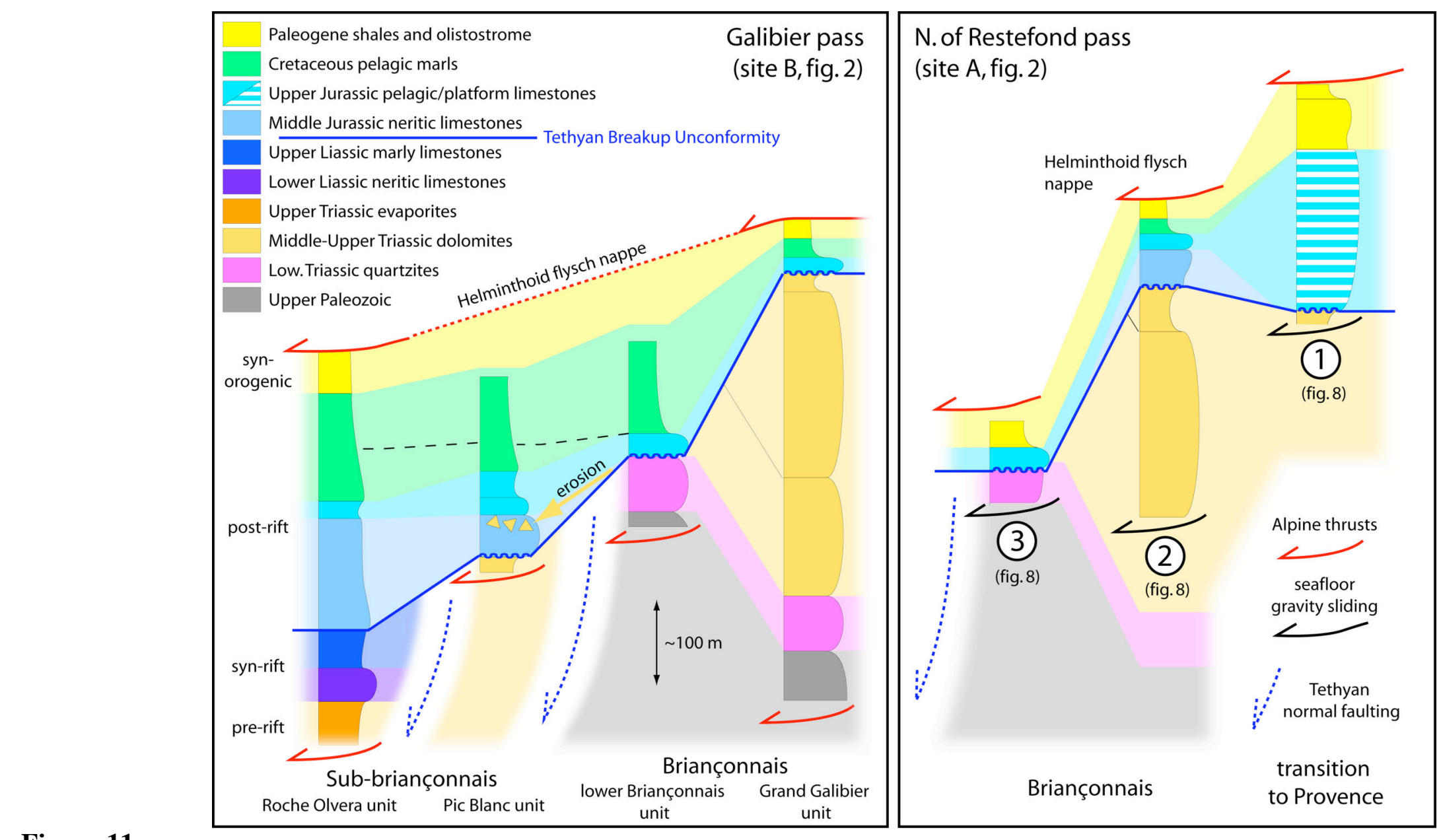

\section{Figure 11:}

Statigraphic content of the blocks hanging over the Restefond paleoslope (right part; see fig. 8; location A fig. 2), and comparison with the thrust sheets of the Galibier area (left part; location B, fig. 2). The strong variations observed in the Mesozoic series show that the Restefond blocks (right) are issued from a paleogeographic hinge zone inherited from the Tethyan rifting. The same statement can be done about the Galibier thrust-sheets (left), except that they were more severly overprinted by top-to-the west transport (deformation D3) in the hangingwall of the CPT. This comparison also supports an important northward or northwestward displacement of the Internal zones with respect to the Embrunais nappes. 


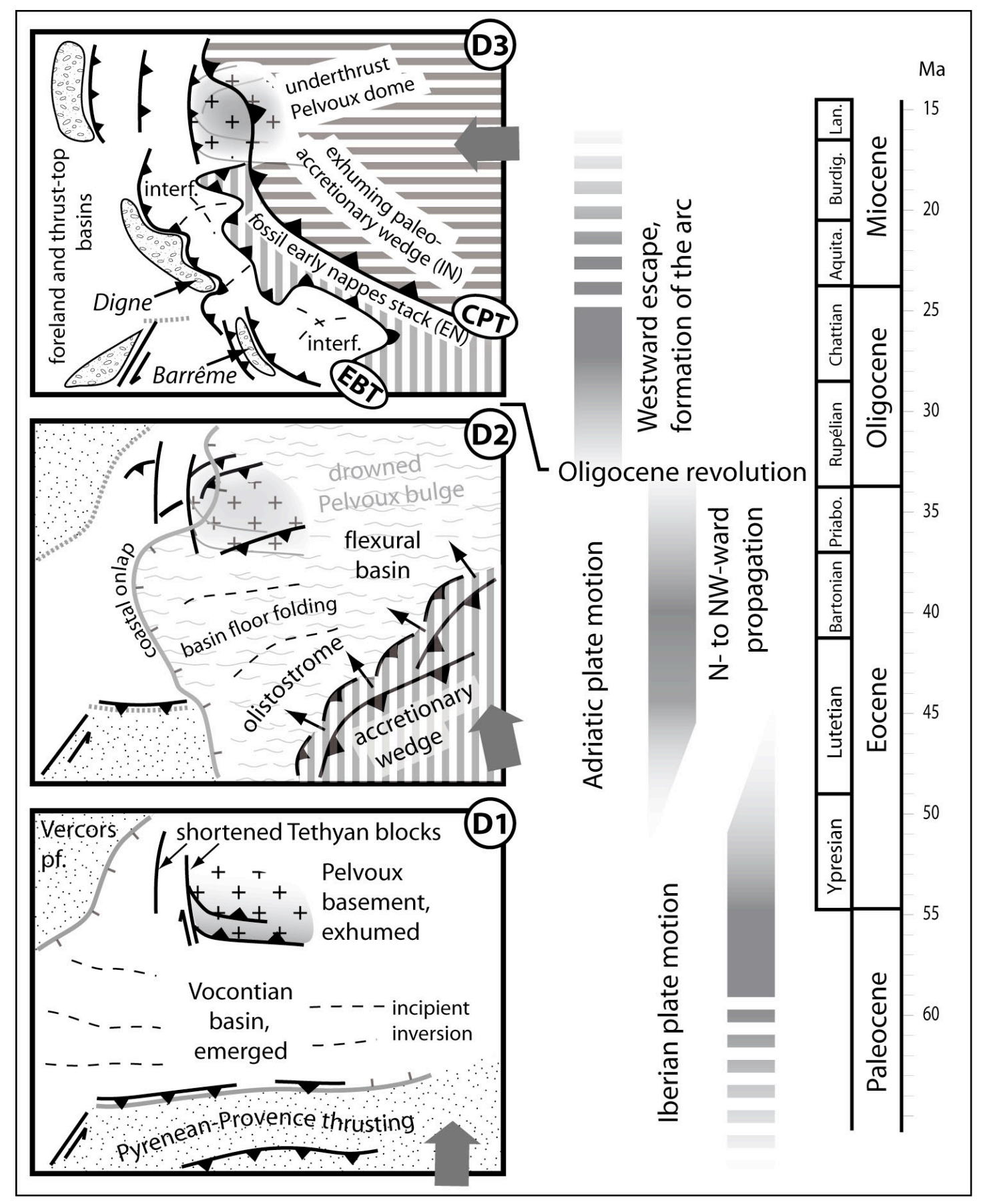

Figure 12:

Summary sketch of the Paleogene evolution of the Alpine foreland in the southern part of the Western Alps. The stages of deformation D1 to D3 refer to the deformation history presented in the text:

The D1 structures and basement exhumation are sealed by Priabonian sediments to the south of the Pelvoux massif, but are not dated. The required N-S shortening component is assigned to the Eocene motion of the Iberian plate whose effects are known in the Pyrenean and Provence realms (\$3.2).

The D2 deformation is expected to occur diachronously in the foreland of the propagating accretionary wedge (vertical hatching), and follows shortly the NNW- to NW-ward propagation of the flexural basin (\$4). It corresponds to the continental subduction stage, and it reached the Pelvoux area around the Eocene-Oligocene boundary.

The D3 collision stage overprinted completely the previous orogenic wedge, which was indented westwards by the Internal metamorphic nappes stack (horizontal hatching), giving birth to the western Alpine arc (\$5). This overprint is shown by interference structures, deformation and uplift of the previously emplaced, low metamorphic grade nappes (EN, vertical hatching), whose erosion feeded the molasse basins together with metamorphic rocks issued from the exhuming paleo-accretionnary wedge (IN). 


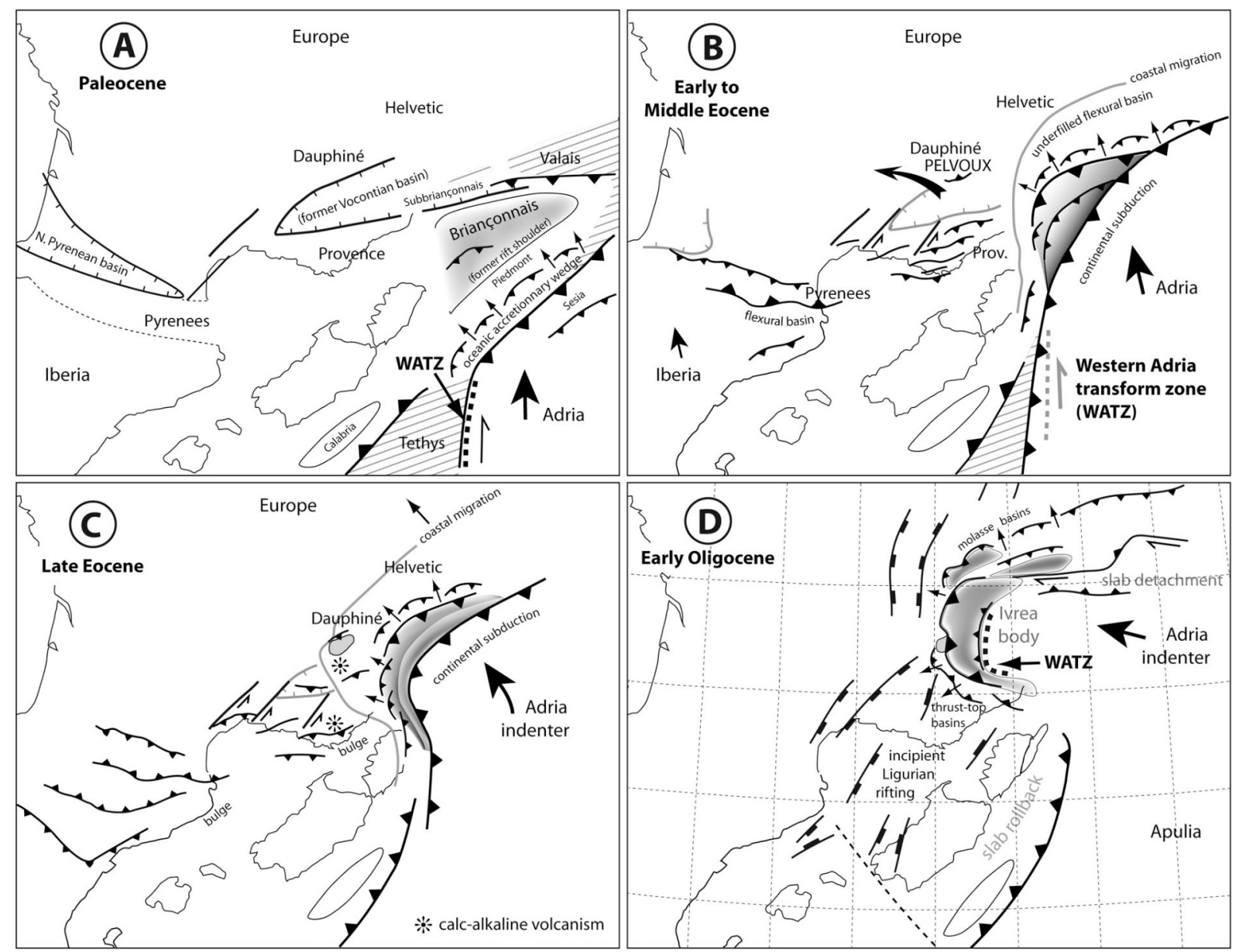

Figure 13 :

Proposed palispastic evolution of the western Alpine realm and surrounding areas. The reconstruction considers both paleogeographical and paleostructural constraints from the literature, such as coastal migration of the flexural basin after Ford et al. (2006) and the estimated location of the Adriatic microplate after the sequential restoration of Schmid \& Kissling (2000) and Handy et al. (2010) and more open choices such as the western termination of the Valais ocean (A).

It is proposed that, before Eocene, the Western Adria Transform Zone (WATZ) bounded a NW-dipping subduction zone beneath Corsica-Sardinia-Calabria, from a SE-dipping zone beneath Adria. The continentward propagation of this transform zone allowed the Briançonnais terrane to be separated from the Iberian plate and integrated in the Alpine accretionnary prism, the Adriatic crust and upper mantle therefore overlying the European crust. From Early Oligocene onwards, the northern part of Adria rotated and moved westwards. The rectilinear western boundary of the Ivrea upper mantle indenter which cores the Oligocene to present arc could be a relict of the WATZ. 